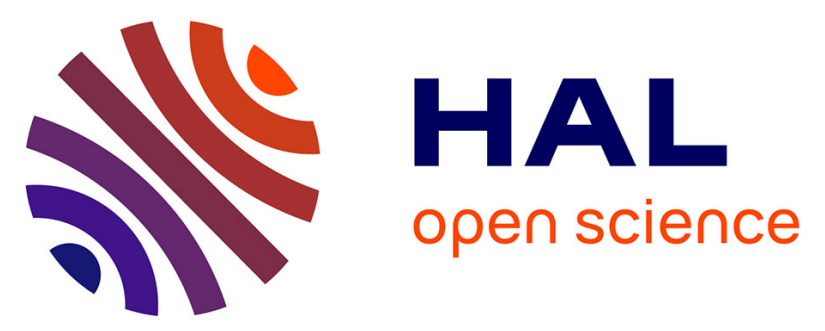

\title{
Oxidation of Cymantrene Analogues of Ferrocifen: Electrochemical, Spectroscopic, and Computational Studies of the Parent Complex 1,1'-Diphenyl-2-cymantrenylbutene
}

Kan Wu, Ji Young Park, Rachael Al-Saadon, Hyerim Nam, Yujin Lee, Siden Top, Gérard Jaouen, Mu-Hyun Baik, William E. Geiger

\section{To cite this version:}

Kan Wu, Ji Young Park, Rachael Al-Saadon, Hyerim Nam, Yujin Lee, et al.. Oxidation of Cymantrene Analogues of Ferrocifen: Electrochemical, Spectroscopic, and Computational Studies of the Parent Complex 1,1'-Diphenyl-2-cymantrenylbutene. Organometallics, 2018, 37 (12), pp.1910-1918. 10.1021/acs.organomet.8b00186 . hal-01961086

\section{HAL Id: hal-01961086 https://hal.sorbonne-universite.fr/hal-01961086}

Submitted on 19 Dec 2018

HAL is a multi-disciplinary open access archive for the deposit and dissemination of scientific research documents, whether they are published or not. The documents may come from teaching and research institutions in France or abroad, or from public or private research centers.
L'archive ouverte pluridisciplinaire HAL, est destinée au dépôt et à la diffusion de documents scientifiques de niveau recherche, publiés ou non, émanant des établissements d'enseignement et de recherche français ou étrangers, des laboratoires publics ou privés. 


\title{
Oxidation of Cymantrene Analogues of Ferrocifen: Electrochemical, Spectroscopic, and Computational Studies of the Parent Complex, 1,1'- Diphenyl, 2-cymantrenylbutene
}

\author{
Kan Wu,${ }^{\dagger}$ Ji Young Park, ${ }^{\dagger}$ Rachael Al-Saadon,,$"$ Hyerim Nam, $,{ }^{\star}, \perp$ Yujin Lee, ${ }^{\ddagger} \S_{, \perp}$ Siden Top, ${ }^{\#}$ Gérard \\ Jaouen, ${ }^{\#, \nabla}$ \\ Mu Hyun Baik ${ }^{\ddagger},{ }^{*}$ and William E. Geiger ${ }^{\dagger} * *$ \\ 'Department of Chemistry, University of Vermont, Burlington, VT 05405, USA, \\ ${ }^{\ddagger}$ Center for Catalytic Hydrocarbon Functionalizations, Institute for Basic Science (IBS), Daejeon 34141, South \\ Korea. \\ ${ }^{\S}$ Department of Chemistry, Korea Advanced Institute of Science and Technology (KAIST), Daejeon 34141, \\ South Korea. \\ "Department of Chemistry, Duke University, Durham, NC 27708, USA \\ ${ }^{\#}$ Sorbonne Université, UPMC, CNRS, Institut Parisien de Chimie Moléculaire (IPCM), UMR 8232, 4 place \\ Jussieu, 75005 Paris, France \\ ${ }^{\nabla}$ PSL, Chimie Paris Tech, 11 rue Pierre and Marie Curie, F-75005 Paris, France \\ ${ }^{\perp}$ Present address: Samsung Electronics, Suwon 16677, South Korea \\ *Corresponding author:William.Geiger@uvm.edu, mbaik2805@kaist.ac.kr
}

KEYWORDS: Breast cancer, Oxidation, Electrochemistry, Bioorganometallics, Cymantrene, Tamoxifen

\section{ABSTRACT}

The oxidative electrochemical behavior of 1-1'-diphenyl-2-cymantrenylbutene (1), a cymantrene analogue of the breast cancer drug ferrocifen, was shown to involve the sequential electron-transfer series $\mathbf{1} / \mathbf{1}^{+} / \mathbf{1}^{2+}$ in dichloromethane/0.05 $\mathrm{M}\left[\mathrm{NBu}_{4}\right]\left[\mathrm{B}\left(\mathrm{C}_{6} \mathrm{~F}_{5}\right)_{4}\right]\left(\mathrm{E}_{1 / 2}\right.$ values $0.78 \mathrm{~V}$ and $1.18 \mathrm{~V}$ vs ferrocene). By employing a combination of spectroscopic and computational techniques, it was shown that the cymantrene functionality plays an important role in dissipating the positive charges in the oxidized compounds and is therefore an active participant in the redox events. The redox-active orbital goes from roughly equal degrees of organometallic and $\pi$-organic (diphenylolefin) makeup in $\mathbf{1}$ to increasingly organic-based fractions in $\mathbf{1}^{+}$and $\mathbf{1}^{2+}$. Structural changes mimicking those of oxidized tetrakis(aryl)ethylenes accompany the one-electron oxidations. There is sufficient unpaired electron density on the manganese center in $\mathbf{1}^{+}$to allow for oxidatively-induced ligand exchange of one or more of the carbonyl ligands with donor ligands, including phosphites and pyridine. The complex $\mathrm{Mn}(\mathrm{CO})_{2} \mathrm{P}(\mathrm{OPh})_{3}\left(\eta^{5}-\mathrm{C}_{5} \mathrm{H}_{4}(\mathrm{Et}) \mathrm{C}=\mathrm{C}\left(\mathrm{C}_{6} \mathrm{H}_{5}\right)_{2}\right)$ was prepared by the 'electrochemical switch' method, 
wherein $\left[\mathrm{Mn}(\mathrm{CO})_{2} \mathrm{P}(\mathrm{OPh})_{3}\left(\eta^{5}-\mathrm{C}_{5} \mathrm{H}_{4}(\mathrm{Et}) \mathrm{C}=\mathrm{C}\left(\mathrm{C}_{6} \mathrm{H}_{5}\right)_{2}\right)\right]^{+}$, produced by the oxidation of $\mathbf{1}$ in the presence of $\mathrm{P}(\mathrm{OPh})_{3}$, was reduced back to the neutral the $\mathrm{CO}$-substituted complex. 


\section{INTRODUCTION}

Modeled in part on the structure of the breast cancer drug tamoxifen (Scheme 1), ${ }^{1-3}$ a large number of ferrocenyl-derivatized diaryl butenes have been tested for activity against cancer cells. ${ }^{4}$ Several of these 'ferrocifen mimics' show promising antiproliferative activity against both estrogen receptor-positive and receptor-negative cell lines. ${ }^{5}$ Replacing the phenyl group of tamoxifen by the ferrocenyl group increases the lipophilicity and, perhaps more importantly, facilitates its one-electron oxidation. Ruthenium and osmium analogues of ferrocifen are less cytotoxic to breast cancer cell lines, a factor attributed to the higher $\mathrm{M}(\mathrm{II}) / \mathrm{M}(\mathrm{III})$ redox potentials of the heavier homologues. ${ }^{5,6}$

\section{Scheme 1}

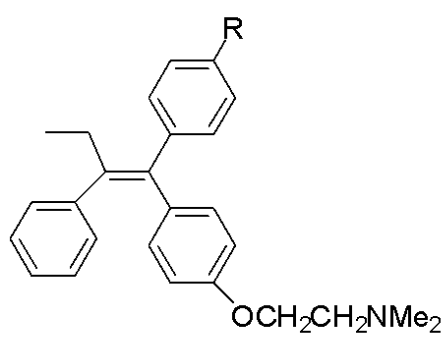

$\mathrm{R}=\mathrm{H}$, tamoxifen $\mathrm{R}=\mathrm{OH}$, hydroxytamoxifen

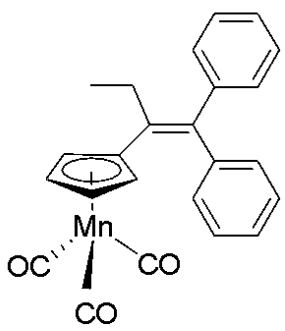

1

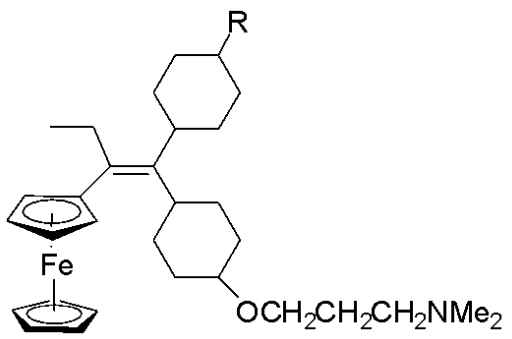

$\mathrm{R}=\mathrm{H}$, ferrocifen

$\mathrm{R}=\mathrm{OH}$, hydroxyfe rrocife $\mathrm{n}$

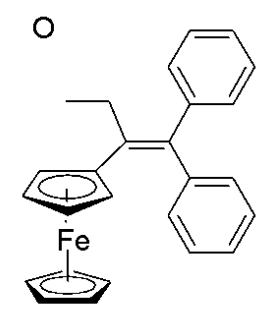

2

Less widely studied are analogues in which the organometallic unit has a half-sandwich structure. Here we describe the oxidation of the cyclopentadienyl manganese tricarbonyl (cymantrene) derivative 1, which may be seen as the parent of a class of group 5 organometallic diaryl butenes. Although compound $\mathbf{1}$ shows only weak antiproliferative action against breast cancer cell lines, ${ }^{7}$ other cymantrenyl-labelled poly(aryl) butenes exhibit significant activity. ${ }^{89}$ An unexplored aspect of the cymantrenyl-tagged compounds is that dramatic changes in the redox potential and other properties of 1 may be obtained with derivatives in which one or more carbonyl group is replaced by an electrondonating ligand. ${ }^{10}$ For example, the $\mathrm{E}_{1 / 2}$ of the one-electron oxidation of $\mathrm{MnCp}(\mathrm{CO})_{2}\left(\mathrm{PPh}_{3}\right)$ is $650 \mathrm{mV}$ negative of that of $\mathrm{MnCp}(\mathrm{CO})_{3}{ }^{11,12}$, and even greater shifts are possible with double substitution of the CO ligands. ${ }^{13}$ To better understand these systems, we prepared several diaryl butenes substituted at the 2-butenyl position with cyclopentadienyl manganese tricarbonyl groups, and investigated their oxidative redox properties. The communication describing our preliminary experimental findings on $\mathbf{1}^{14}$ is supplemented in the present paper by calculations giving information on the electronic and 
molecular structures of $\mathbf{1}$ and its oxidation products, $\mathbf{1}^{+}$and $\mathbf{1}^{2+}$. We also describe the oxidativelyinduced substitution of carbonyl groups in $\mathbf{1}$ by donor ligands and report the $\mathrm{E}_{1 / 2}$ potentials of the resulting carbonyl-substituted complexes.

The potential redox activity of organometallic-tagged tamoxifen-type compounds is not restricted to the organometallic unit. In fact, the 1,1 '-diarylethylenyl position of these molecules is expected to be redox-active, based on the fact that most poly(aryl)ethylenes undergo two chemically reversible oxidations at accessible potentials. For example, in dichloromethane/0.1 $\mathrm{M}\left[\mathrm{NBu}_{4}\right]\left[\mathrm{PF}_{6}\right]$, tetraanisylethylene is converted to its radical cation and dication at $0.41 \mathrm{~V}$ and $0.53 \mathrm{~V} v s$ ferrocene $(\mathrm{FcH})$, respectively. ${ }^{16-18}$ Oxidation potentials of the diaryldiethyl analogue, 3,4-bis(anisyl)-3-hexene, are only slightly more positive. ${ }^{17}$ More recent papers on tetraarylethylene redox chemistry are available. ${ }^{18-20}$ Consistent with the expectation that a ferrocenyl group should be easier to oxidize than a diarylethylenyl group, the first oxidations of 1,1'-diphenyl, 2-ferrocenylbutene, $\mathbf{2}$, and other members of the ferrocifen family give monocations that have essentially ferrocenium [Fe(III)] character. ${ }^{21-23} \mathrm{In}$ contrast, oxidation of the manganese center in $\mathbf{1}$ is expected to be more difficult than oxidation of the diarylethylenyl group, based on the fact that $\mathrm{E}_{1 / 2}$ for the oxidation of cymantrene is $0.91 \mathrm{~V} v s \mathrm{FcH} .{ }^{24}$ Thus, radical cations of the type $\mathbf{1}^{+}$might be expected to have spin and charge that is highly localized in the diarylethylenyl ( $\pi$-ligand) part of the molecule. In fact, as we show by both experiment and calculation, the HOMO of the parent complex $\mathbf{1}$, as well as the SOMO of $\mathbf{1}^{+}$, have essentially equal amounts of organometallic and $\pi$-organic character. It is of practical importance to obtain a measure of the metal $v s \pi$-ligand makeup of these systems owing to the fact that delocalization between the organometallic group and the diarylethylenyl group is thought to facilitate the follow-up reactions of positively-charged ferrocifen derivatives that exhibit strong biological activity. ${ }^{5,21-23}$ Furthermore, it has been shown that the degree of metal-ligand charge delocalization in a cymantrene-type radical cation affects the rates of carbonyl substitution reactions for the $\mathrm{Mn}(\mathrm{CO})_{3}$ group. ${ }^{25}$

The present study was simplified by the fact that the anodic electron-transfer reactions of $\mathbf{1}$ are not complicated by the types of follow-up reactions that would be expected if the aryl moieties in $\mathbf{1}$ contained hydroxyl or other groups that are subject to oxidative activation. A separate study has been carried out on the $p$-hydroxyl and $p$-methoxy-substituted analogues of $\mathbf{1}$, and those results will be reported in a separate paper.

\section{EXPERIMENTAL DETAILS}

All operations were carried out under nitrogen or argon using either Schlenk or drybox techniques. Solvents were dried and purified either by refluxing them in drying agents or by passing them down an alumina column under argon. Infrared spectra were obtained on either an IRFT BOMEM Michelson-100 spectrometer or an ATI-Mattson Infinity Series FTIR operating at a 
resolution of $4 \mathrm{~cm}^{-1}$. In situ IR spectroelectrochemistry was carried out with a Remspec, Inc., fiberoptic system using a methodology previously described. ${ }^{26}{ }^{1} \mathrm{H}$ and ${ }^{13} \mathrm{C}$ NMR spectra were obtained with Bruker spectrometers and mass spectra were obtained with a Nermag R 10-10C unit using chemical ionization. EPR spectra were obtained with a Bruker ESP 300E spectrometer. $\left[\mathrm{NBu}_{4}\right]\left[\mathrm{B}\left(\mathrm{C}_{6} \mathrm{~F}_{5}\right)_{4}\right]$ was recrystallized from dichloromethane/diethyl ether after being prepared by metathesis of $\left[\mathrm{NBu}_{4}\right] \mathrm{Br}$ and $\mathrm{K}\left[\mathrm{B}\left(\mathrm{C}_{6} \mathrm{~F}_{5}\right)_{4}\right]{ }^{27}$

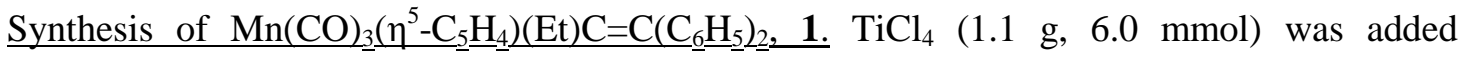
dropwise to a suspension of zinc powder $(0.78 \mathrm{~g}, 12.0 \mathrm{mmol})$ in $20 \mathrm{~mL}$ THF at $0^{\circ} \mathrm{C}$. A blue mixture was obtained, which was refluxed for $2 \mathrm{~h}$, whereupon the solution became black. The reaction medium was allowed to come to room temperature, after which a solution of benzophenone $(0.73 \mathrm{~g}, 4.0$ mmole) and propionylcymantrene ${ }^{28}(0.52 \mathrm{~g}, 2.0 \mathrm{mmole})$ in $10 \mathrm{~mL}$ THF was added dropwise. The resulting mixture was refluxed for $4 \mathrm{~h}$, after which it was allowed to cool to room temperature and then poured into $100 \mathrm{~mL}$ water and acidified to $\mathrm{pH} 1$ with a diluted aqueous $\mathrm{HCl}$ solution. After the solution was extracted by dichloromethane $(3 \times 50 \mathrm{~mL})$ and washed with $50 \mathrm{~mL}$ water, the solvent was evaporated, leaving $1.17 \mathrm{~g}$ of crude product that was chromatographed on a silica gel column with 1:50 diethyl ether/petroleum ether as eluent, giving $0.38 \mathrm{~g}(46 \%)$ of the desired product. It was recrystallized from diethyl ether/pentane, giving yellow crystals of m.p. $102^{\circ} \mathrm{C} .{ }^{1} \mathrm{H}$ NMR $(300 \mathrm{MHz}$, $\mathrm{d}^{6}$-acetone): $\delta$ 7.39-7.17 (m, 10H, aromatic rings), $4.77\left(\mathrm{t}, J=2.1 \mathrm{~Hz}, 2 \mathrm{H}, \mathrm{C}_{5} \mathrm{H}_{4}\right), 4.62(\mathrm{t}, J=2.1 \mathrm{~Hz}$, $\left.2 \mathrm{H}, \mathrm{C}_{5} \mathrm{H}_{4}\right), 2.31$ (q, $\left.2 \mathrm{H}, J=7.5 \mathrm{~Hz}, \mathrm{CH}_{2} \mathrm{CH}_{3}\right), 1.08\left(\mathrm{t}, 3 \mathrm{H}, \mathrm{J}=7.5 \mathrm{~Hz}, \mathrm{CH}_{2} \mathrm{CH}_{3}\right) .{ }^{13} \mathrm{C}$ NMR $(75.5 \mathrm{MHz}$, $\mathrm{d}^{6}$-acetone): $\delta 15.4\left(\mathrm{CH}_{3}\right), 28.5\left(\mathrm{CH}_{2}\right), 82.8$ and $85.7\left(\mathrm{CH}, \mathrm{C}_{5} \mathrm{H}_{4}\right), 105.1\left(\mathrm{C}_{\mathrm{ip}}, \mathrm{C}_{5} \mathrm{H}_{4}\right), 127.7,129.3$, 129.4, 129.5 and $130.1\left(\mathrm{CH}_{\text {arom }}\right), 132.9,143.7,144.2$ and $144.4\left(\mathrm{C}_{\mathrm{q}}\right.$ of two $\mathrm{C}_{6} \mathrm{H}_{4}$ and $\mathrm{C}=\mathrm{C}$. IR $\left(\mathrm{CH}_{2} \mathrm{Cl}_{2}\right)$ $v_{\mathrm{CO}} 2017,1932 \mathrm{~cm}^{-1}$. MS (CI): $411[\mathrm{MH}]^{+} ; 326[\mathrm{M}-3 \mathrm{CO}]^{+}$. Anal: Calc for $\mathrm{C}_{24} \mathrm{H}_{19} \mathrm{O}_{3} \mathrm{Mn}: \mathrm{C}, 70.25, \mathrm{H}$, 4.67. Found: C, 69.75, H, 4.55 .

Synthesis of $\left.\mathrm{Mn}(\mathrm{CO})_{2} \underline{P}(\mathrm{OPh})_{3} \underline{\eta^{5}}-\mathrm{C}_{\underline{5}} \underline{\mathrm{H}}_{4}(\mathrm{Et}) \mathrm{C}=\mathrm{C}\left(\mathrm{C}_{6} \underline{\mathrm{H}_{5}}\right)_{2} \underline{2}\right) .32 \mathrm{~mL}$ of a solution of $\mathrm{CH}_{2} \mathrm{Cl}_{2} / 0.05$ $\mathrm{M}\left[\mathrm{NBu}_{4}\right]\left[\mathrm{B}\left(\mathrm{C}_{6} \mathrm{~F}_{5}\right)_{4}\right]$ that was $3.04 \mathrm{mM}$ in $\mathbf{1}(40 \mathrm{mg})$ and $4.5 \mathrm{mM}$ in $\mathrm{P}(\mathrm{OPh})_{3}(44 \mathrm{mg})$ was placed in the working compartment of a three-compartment electrochemical cell. With application of an applied potential of $1.0 \mathrm{~V} v s$ ferrocene to a platinum basket electrode, the solution was electrolyzed for 30 $\mathrm{min}$, at which time 1.0 F had been passed and the solution had changed color from its original pale yellow to pink. After $\mathrm{CV}$ scans were obtained that showed that $\mathbf{1}$ had been quantitatively converted to $\left[\mathrm{Mn}(\mathrm{CO})_{2} \mathrm{P}(\mathrm{OPh})_{3}\left(\eta^{5}-\mathrm{C}_{5} \mathrm{H}_{4}(\mathrm{Et}) \mathrm{C}=\mathrm{C}\left(\mathrm{C}_{6} \mathrm{H}_{5}\right)_{2}\right)\right]^{+}\left(\mathrm{E}_{1 / 2}=0.46 \mathrm{~V}\right)$, the applied potential at the platinum basket was changed to $0.1 \mathrm{~V}$. This initiated the reduction of the phosphite-substituted cation and resulted in passage of $0.85 \mathrm{~F}$ as the solution went from pink to green. The working compartment solution was evaporated while being protected from light. A pentane extract of the crude product was evaporated to dryness and the resulting yellow solid was spotted on an alumina column with dichloromethane and eluted with diethyl ether. The yellow band trailing the unreacted triphenyl phosphite was evaporated, giving $27 \mathrm{mg}(40 \%)$ of a yellow powder that was identified as 
$\mathrm{Mn}(\mathrm{CO})_{2} \mathrm{P}(\mathrm{OPh})_{3}\left(\eta^{5}-\mathrm{C}_{5} \mathrm{H}_{4}(\mathrm{Et}) \mathrm{C}=\mathrm{C}\left(\mathrm{C}_{6} \mathrm{H}_{5}\right)_{2}\right)$ based on its IR spectrum $\left(v_{\mathrm{co}}=1956,1893 \mathrm{~cm}^{-1}\right.$ in $\left.\mathrm{CH}_{2} \mathrm{Cl}_{2}\right)$ and the fact that the potential of its reversible oxidation $\left(\mathrm{E}_{1 / 2}=0.46 \mathrm{~V}\right)$ matched that obtained from cyclic voltammetry scans when $\mathbf{1}$ was oxidized in the presence of triphenyl phosphite (see Results section).

Electrochemistry. Voltammetry was carried on with a three-electrode format, using a Pt wire for the auxiliary electrode and a homemade $\mathrm{Ag} / \mathrm{AgCl}$ electrode for the experimental reference electrode. The latter consisted of a $\mathrm{AgCl}$-coated silver wire that was immersed in a solution of $0.05 \mathrm{M}$ $\left[\mathrm{NBu}_{4}\right]\left[\mathrm{B}\left(\mathrm{C}_{6} \mathrm{~F}_{5}\right)_{4}\right]$ in dichloromethane which was separated from the working electrode compartment by a fine-porosity glass frit. The potentials in this paper are all referenced to the ferrocene/ferrocenium couple, ${ }^{29}$ the potential of which was obtained by the in-situ method ${ }^{30}$ at an appropriate point in the experiment. Working electrodes for voltammetry measurements were 1 or $2 \mathrm{~mm}$ glassy carbon disks obtained from Bioanalytical Systems and polished before use with Buehler diamond paste. A platinum basket working electrode was used in a three-compartment $\mathrm{H}$-cell for bulk electrolysis. The potentiostat was a PARC Model 273 interfaced to a computer controlled by homemade software. The temperature of the electrolyte solution was controlled to within $1^{\circ} \mathrm{C}$ by a TFS Flexi-Cool system. In general, the electrochemical procedures followed those described in an earlier paper. ${ }^{24}$ Well-known diagnostics ${ }^{31}$ were applied to cyclic voltammetry measurements at different scan rates to check for diffusion-control and chemical and electrochemical reversibility of the redox couples. Digital simulations were carried out using Digisim 3.0 (Bioanalytical Systems) on background-subtracted cyclic voltammograms.

Computational Methods. All calculations were performed at the B3LYP-D3 ${ }^{32}$ level of density functional theory implemented in the QChem 4.4 package. ${ }^{33}$ For geometry optimizations, 6-31G** level of basis set ${ }^{34}$ was used for all main group elements and Mn was represented using the Los Alamos LANL2DZ basis set $^{35}$, which is a double zeta quality basis set including effective core potentials. Convergence to local minima was confirmed by vibrational frequency calculations that showed no imaginary frequency. The energies of these species were re-evaluated using the $c c-p V T Z{ }^{36}$ basis set for main group elements and LANL2DZ for Mn. This is a well-established and thoroughly tested protocol for calculating redox potentials ${ }^{37}$ and modeling redox processes. Solvation energy corrections were obtained using a continuum solvation model (c-pcm) employing the double zeta basis set and zero-point vibrational energy and entropy corrections were obtained also using the double zeta basis set. The dielectric constant of dichloromethane was set to 9.08 at room temperature. ${ }^{38}$ Vibrational frequencies computed using the harmonic oscillator model at the B3LYP/double-zeta level of theory were scaled by a factor of $0.9613 .{ }^{39}$ Cartesian coordinates of all computed structures were given in supporting information. The $\%$ orbital contribution for fragments are obtained using the Chemissian ${ }^{40}$ program. 


\section{RESULTS AND DISCUSSION}

Oxidation of 1. Electrochemical studies of the anodic reactions of 1 were carried out in dichloromethane, using either $\left[\mathrm{NBu}_{4}\right]\left[\mathrm{PF}_{6}\right]$ or $\left[\mathrm{NBu}_{4}\right]\left[\mathrm{B}\left(\mathrm{C}_{6} \mathrm{~F}_{5}\right)_{4}\right]$ as the supporting electrolyte. Owing to the fact that a single cyclic voltammetry $(\mathrm{CV})$ scan through the first oxidation wave resulted in severe electrode fouling in $\left[\mathrm{PF}_{6}\right]^{-}$-based electrolyte, the electrochemical work reported in this paper was carried out in $\left[\mathrm{B}\left(\mathrm{C}_{6} \mathrm{~F}_{5}\right)_{4}\right]^{-}$-based electrolyte, the use of which circumvented adsorption problems and gave reproducible voltammograms at glassy carbon electrodes. Positive-going CV scans of the parent compound 1 showed two reversible one-electron oxidations at $E_{1 / 2}(1)=0.78 \mathrm{~V}$ and $E_{1 / 2}(2)=$ $1.18 \mathrm{~V}$ vs $\mathrm{FeCp}_{2}{ }^{0 /+}$. That the two reactions are diffusion-controlled, quasi-Nernstian, processes (see electron-transfer series in Eq 1) was confirmed by evaluation of the standard CV diagnostic criteria ${ }^{31}$ and by digital

$$
1 \underset{0.78 \mathrm{~V}}{\stackrel{-\mathrm{e}^{-}}{\rightleftharpoons}} \mathbf{1}^{+} \stackrel{-\mathrm{e}^{-}}{\rightleftharpoons} \mathbf{1}^{2+} \quad \Delta \mathrm{E}_{1 / 2}=400 \mathrm{mV}
$$

simulations (Figure 1). The latter were used to determine the diffusion coefficient of $\mathbf{1}$ as $1.5 \times 10^{-5}$ $\mathrm{cm}^{2} \mathrm{~s}^{-1}$ at $298 \mathrm{~K}$. Both $\mathbf{1}^{+}$and $\mathbf{1}^{2+}$ are stable on the electrolysis time scale and were characterized by spectroscopic methods.

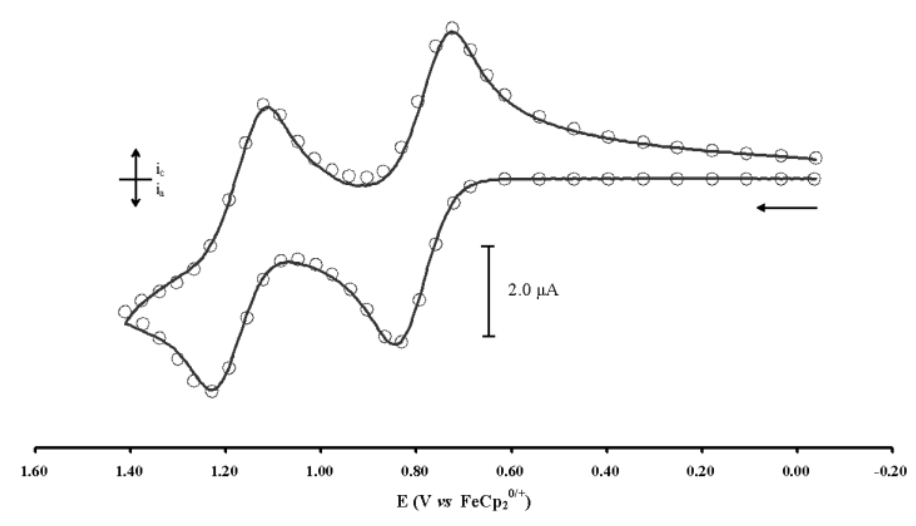

Figure 1. Experimental (solid line) and simulated (circles) CVs of $1.25 \mathrm{mM} 1$ in $\mathrm{CH}_{2} \mathrm{Cl}_{2} / 0.05 \mathrm{M}$ $\left[\mathrm{NBu}_{4}\right]\left[\mathrm{B}\left(\mathrm{C}_{6} \mathrm{~F}_{5}\right)_{4}\right]$ at $298 \mathrm{~K}, 0.2 \mathrm{~V} \mathrm{~s}^{-1}, 1 \mathrm{~mm}$ glassy carbon electrode.

Spectral characterization of Oxidation Products. To more broadly characterize the oxidation products, the monocation and dication of $\mathbf{1}$ were generated by bulk anodic electrolysis at $273 \mathrm{~K}$. Electrolysis at $\mathrm{E}_{\text {appl }}=0.9 \mathrm{~V}$ consumed $1.0 \mathrm{~F}$, giving complete conversion to the monocation $\mathbf{1}^{+}$, as shown by linear scan voltammetry. Continuation of the electrolysis at $\mathrm{E}_{\text {appl }}=1.3 \mathrm{~V}$ consumed an additional $1.0 \mathrm{~F}$ and produced the dication $\mathbf{1}^{2+}$ in high yield. Cathodic re-electrolysis at $\mathrm{E}_{\text {appl }}=0 \mathrm{~V}$ 
regenerated over $90 \%$ of the neutral starting material. The favorable stabilities of the oxidation products facilitated their spectral characterization. Carbonyl-region IR spectra were obtained by either the in situ fiber-optic method ${ }^{27}$ or by simple transfer of an electrolysis sample to a solution IR cell. Examples of in situ spectra are shown in Figures 2 and 3 for the stepwise conversion of $\mathbf{1}$ to $\mathbf{1}^{+}$and $\mathbf{1}^{+}$ to $\mathbf{1}^{2+}$, respectively.

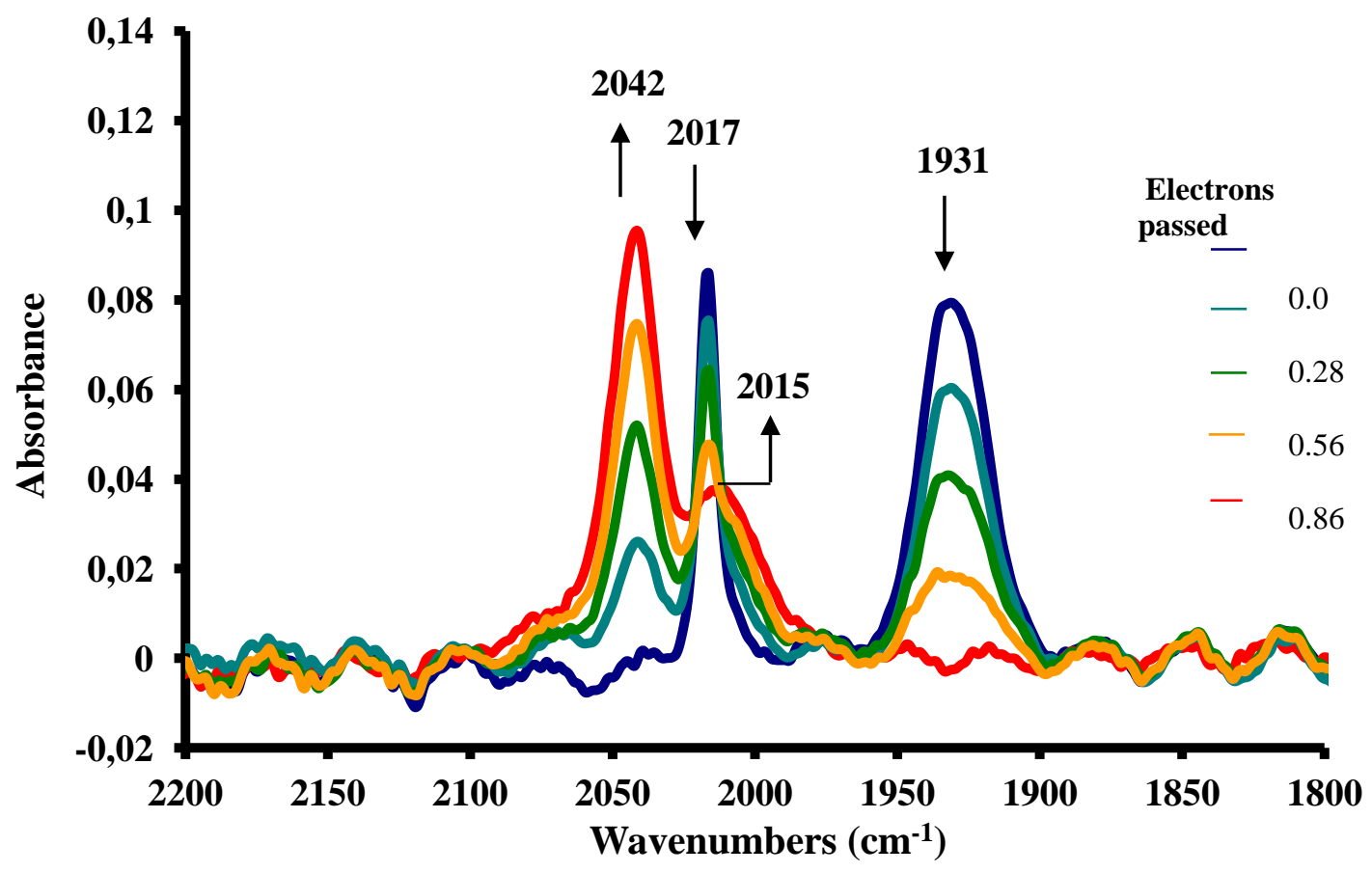

Figure 2. Fiber-optic IR spectra of solutions of $1.5 \mathrm{mM} 1$ in $\mathrm{CH}_{2} \mathrm{Cl}_{2} / 0.05 \mathrm{M}\left[\mathrm{NBu}_{4}\right]\left[\mathrm{B}\left(\mathrm{C}_{6} \mathrm{~F}_{5}\right)_{4}\right]$ as the bulk oxidation proceeded at $273 \mathrm{~K}$ to $1 \mathrm{~F}$ passed, $\mathrm{E}_{\text {appl }}=0.9 \mathrm{~V}$. 


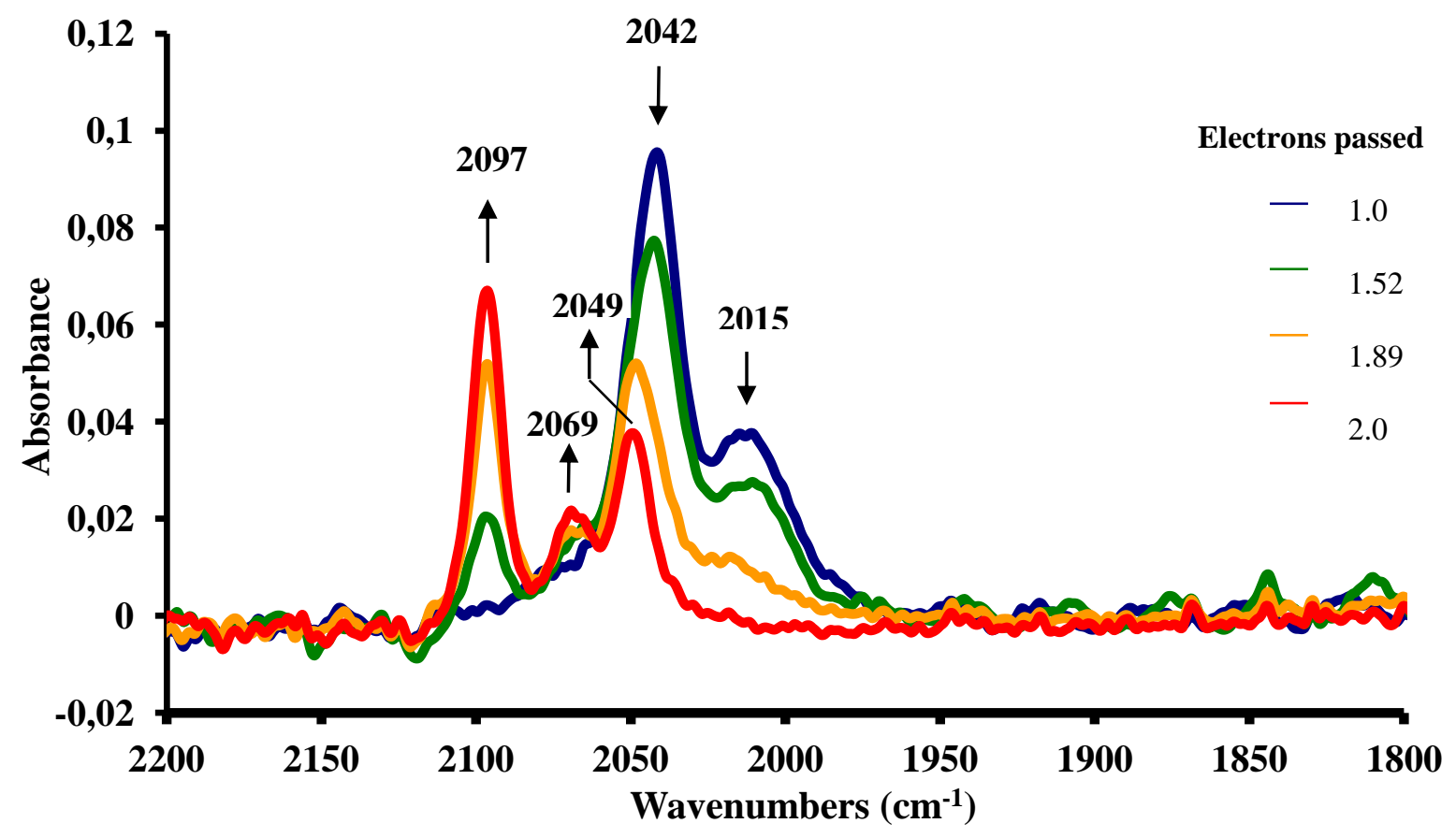

Figure 3. Fiber-optic IR spectra of $1.5 \mathrm{mM} 1$ in $\mathrm{CH}_{2} \mathrm{Cl}_{2} / 0.05 \mathrm{M}\left[\mathrm{NBu}_{4}\right]\left[\mathrm{B}\left(\mathrm{C}_{6} \mathrm{~F}_{5}\right)_{4}\right]$ as the bulk oxidation proceeded at $273 \mathrm{~K}$ from $1 \mathrm{~F}$ passed to $2 \mathrm{~F}$ passed, $\mathrm{E}_{\text {appl }}=1.3 \mathrm{~V}$.

It is well known that metal-carbonyl stretching frequencies increase with increasing positive charge at the metal center as back-donation of electron density from the metal to the carbonyl $\pi^{*}$ orbital is reduced, resulting in a stronger $\mathrm{C}-\mathrm{O}$ bond. ${ }^{41-45}$ In the present case, it is informative to compare the increases in the average carbonyl stretching frequencies for $\mathbf{1}^{+}$and $\mathbf{1}^{2+}$ with those observed for the oxidation of cymantrene itself ${ }^{24}$ (see Table 1). Note that we use a weighted average of the three carbonyl absorption frequencies, counting the asymmetric stretch twice for compounds in which the two asymmetric $v_{\mathrm{CO}}$ bands are not resolved. This analysis shows that removal of two electrons from 1 is required to produce the same degree of spectral shift $\left(+112 \mathrm{~cm}^{-1}\right)$ as seen with removal of a single electron from cymantrene $\left(+115 \mathrm{~cm}^{-1}\right)$. In concert, the average increase in $v_{\mathrm{CO}}(+64$ $\mathrm{cm}^{-1}$ ) for the monocation $\mathbf{1}^{+}$is only slightly more than half of that observed for the cymantrene radical cation. We have also computed the vibrational frequencies using DFT-calculations and the results are convincingly similar, although there the computed energy shifts are slightly smaller. Calculations confirm that to reproduce the frequency shift calculated for the oxidation of cymantrene $\left(+82 \mathrm{~cm}^{-1}\right)$, two electrons must be removed from $\mathbf{1}$ to give a shift of $+89 \mathrm{~cm}^{-1}$ in $\mathbf{1}^{2+}$. Significant fractions of the positive charges reside on the dipenylethylenyl segment as electrons are removed from the molecule.

The rich contribution of the diphenylethynyl moiety to the SOMO is also indicated by the EPR spectrum of $\mathbf{1}^{+}$, which is not characteristic of a highly metal-centered Mn(II) system. The frozensolution spectrum of $\mathbf{1}^{+}$, shown in Figure 4, is nearly isotropic, with $<\mathrm{g}>\approx 2.01$ and a ${ }^{55} \mathrm{Mn}(\mathrm{I}=5 / 2)$ 
hyperfine splitting (hfs) of approximately $21 \mathrm{G}$. These features are in stark contrast to those reported for $\left[\mathrm{MnCp}(\mathrm{CO})_{3}\right]^{+}$, which has a highly anisotropic g-value and an average $\mathrm{Mn} \mathrm{hfs} \mathrm{of} 70 \mathrm{G} .^{24}$

Table 1. Summary of metal-CO IR absorptions for $\mathbf{1}, \mathbf{1}^{+}$and $\mathbf{1}^{2+}$ in $\mathrm{CH}_{2} \mathrm{Cl}_{2} / 0.05 \mathrm{M}\left[\mathrm{NBu}_{4}\right][\mathrm{TFAB}]$ at $273 \mathrm{~K}$. Data on $\mathrm{MnCp}(\mathrm{CO})_{3}{ }^{0 /+}(298 \mathrm{~K})$ were taken from reference $24{ }^{a}{ }^{\mathrm{a}}\left\langle v_{\mathrm{CO}}\right\rangle\left(\mathrm{cm}^{-1}\right)=\left(v_{\mathrm{sym}}+2 v_{\text {asym }}\right) / 3$ ${ }^{\mathrm{b}}$ average value referenced to neutral compound in $\mathrm{cm}^{-1}$.

\begin{tabular}{|c|c|c|c|c|c|c|c|c|}
\hline & \multicolumn{5}{|c|}{ Experimental } & \multicolumn{3}{c|}{ DFT-Calculated } \\
\hline Compound & $v_{\text {sym }}$ & $v_{\text {asym }}$ & $<v_{\mathrm{CO}}>^{\mathrm{a}}$ & $\Delta<\mathrm{v}_{\mathrm{CO}}>^{\mathrm{0}}$ & $v_{\text {sym }}$ & $v_{\text {asym }}$ & $<\mathrm{v}_{\mathrm{CO}}>^{\mathrm{a}}$ & $\Delta<\mathrm{v}_{\mathrm{CO}}>^{0}$ \\
\hline $\mathrm{MnCp}(\mathrm{CO})_{3}$ & 2022 & 1934 & 1963 & - & 2035 & 1979 & 1998 & - \\
\hline$\left[\mathrm{MnCp}(\mathrm{CO})_{3}\right]^{+}$ & 2118 & 2058 & 2078 & +115 & 2197 & 1959,2085 & 2080 & +82 \\
\hline $\mathbf{1}$ & 2017 & 1931 & 1960 & - & 2028 & 1969,1978 & 1991 & - \\
\hline $\mathbf{1}^{+}$ & 2042 & 2015 & 2024 & +64 & 2056 & 2015,2024 & 2032 & +41 \\
\hline $\mathbf{1}^{2+}$ & 2097 & 2069,2049 & 2072 & +112 & 2104 & 1989,2075 & 2080 & +89 \\
\hline
\end{tabular}

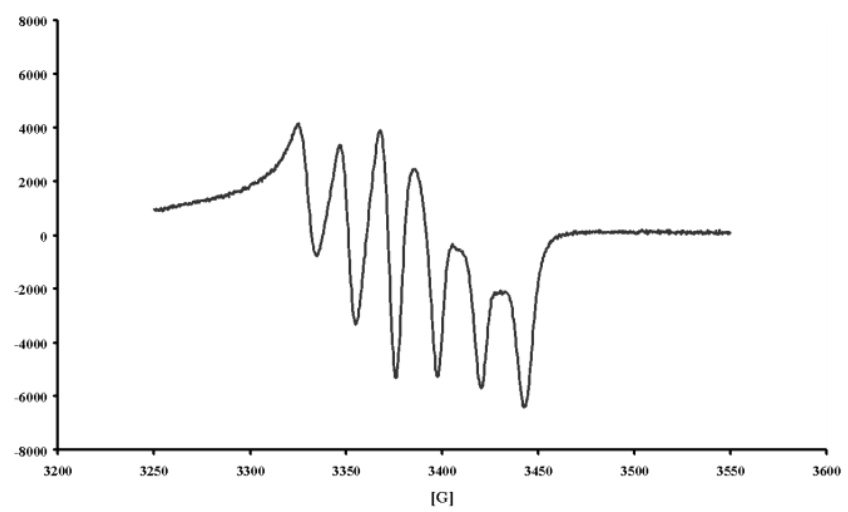

Figure 4. EPR spectrum of $\mathbf{1}^{+}$at $77 \mathrm{~K}$. Sample was prepared by exhaustive electrolysis of $\mathbf{1}$ in $\mathrm{CH}_{2} \mathrm{Cl}_{2} / 0.05 \mathrm{M}\left[\mathrm{NBu}_{4}\right]\left[\mathrm{B}\left(\mathrm{C}_{6} \mathrm{~F}_{5}\right)_{4}\right]$ at $253 \mathrm{~K}, \mathrm{E}_{\text {appl }}=0.9 \mathrm{~V}$.

Calculations: structures and redox-active orbitals. The DFT-optimized structures of $\mathbf{1}, \mathbf{1}^{+}$, and $\mathbf{1}^{2+}$ (Figure 5) reveal how electron removal affects the molecular structures of this series of redox active molecules. In the neutral species $\mathbf{1}$, the double bond between $\mathrm{C} 2$ and $\mathrm{C} 3$ is intact at a bond length of $1.358 \AA$, which is slightly longer than the value $\left(\sim 1.33 \AA\right.$ ) typically seen in simple olefins. ${ }^{46}$ The dihedral angle $(\mathrm{C} 1-\mathrm{C} 2-\mathrm{C} 3-\mathrm{C} 4)$ of $167^{\circ}$ is a bit distorted from that of an ideal planar geometry. Both deviations from ideal olefin structures are due to the steric demands of the substituents in this tetra-substituted olefin. The fact that the C2-C3 bond lengthens by $\sim 0.06 \AA$ to $1.422 \AA$ in $\mathbf{1}^{+}$is a consequence of removal of olefin $\pi$ character, an effect that is enhanced with removal of the second electron. The resulting C2-C 3 bond length of $1.489 \AA$ in $\mathbf{1}^{2+}$ begins to approach that of a standard C-C 
single bond. Decreases in the dihedral angle from the $167^{\circ}$ of $\mathbf{1}$ to $146^{\circ}$ in $\mathbf{1}^{+}$and then to $127^{\circ}$ in $\mathbf{1}^{2+}$ are also consistent with a decreasing degree of double-bond character for $\mathrm{C} 2-\mathrm{C} 3$ as electrons are removed.

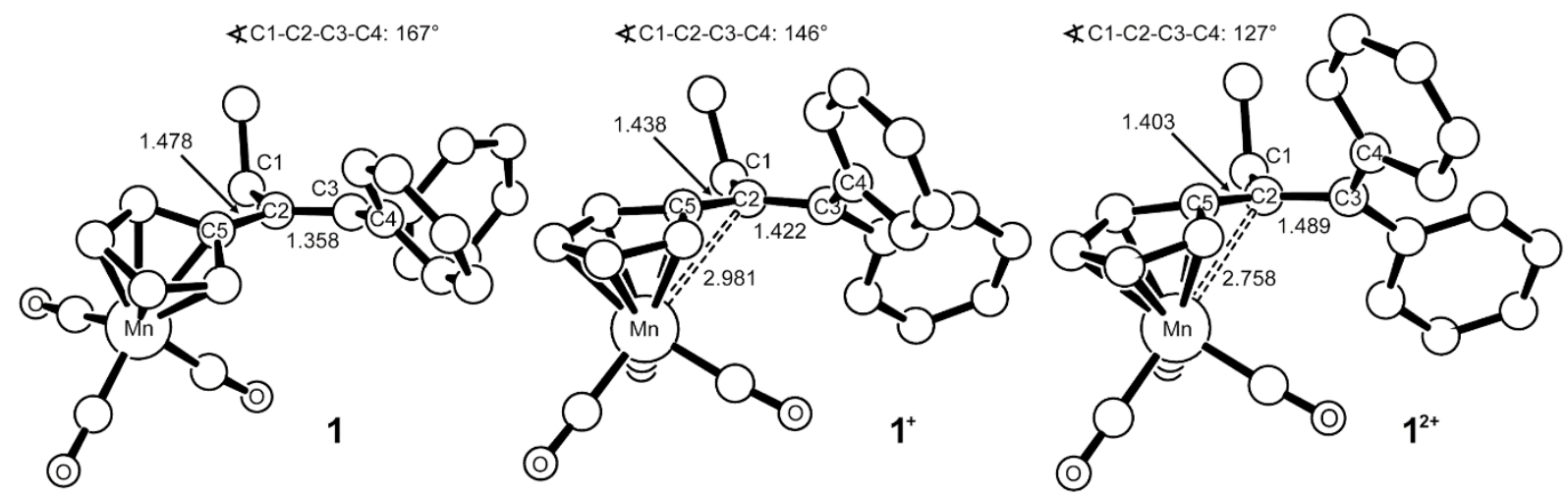

Figure 5. Optimized structures of $\mathbf{1}, \mathbf{1}^{+}$, and $\mathbf{1}^{2+}$. Bond lengths are given in $\AA$.

The calculations also show that there is a significant change in the nature of the metal-ligand bonding as electrons are removed from 1. There is a notable shortening of the $\mathrm{C} 2-\mathrm{C} 5$ distance from 1.478 to 1.438 and 1.403 in $\mathbf{1}, \mathbf{1}^{+}$, and $\mathbf{1}^{2+}$, respectively, consistent with the progress toward a fulvenetype tautomer as the oxidation proceeds. The newly formed quasi-olefinic $\mathrm{C} 2-\mathrm{C} 5$ fragment can then engage the Mn-center. The Mn-C1 distance in $\mathbf{1}$ is $3.231 \AA$, indicating that there is no electronic interaction between these atoms in the neutral complex. As oxidation introduces fulvene-character and a partial double-bond is formed between $\mathrm{C} 2$ and $\mathrm{C} 5$, the $\mathrm{Mn}-\mathrm{C} 2$ distance shortens to 2.981 and finally to $2.758 \AA$ in $\mathbf{1}^{+}$, and $\mathbf{1}^{2+}$, respectively. The structural features of the dication are highly reminiscent of the $\left[\mathrm{Mn}(\mathrm{CO})_{3}\left(\eta^{4}: \eta^{2} \text {-diphenylfulvene }\right)\right]^{+}$structure observed previously by Gleiter. ${ }^{47,48} \mathrm{~A}$ schematic illustration of the interplay between the electronic and molecular structures of the electron-transfer series is shown in Figure 6.

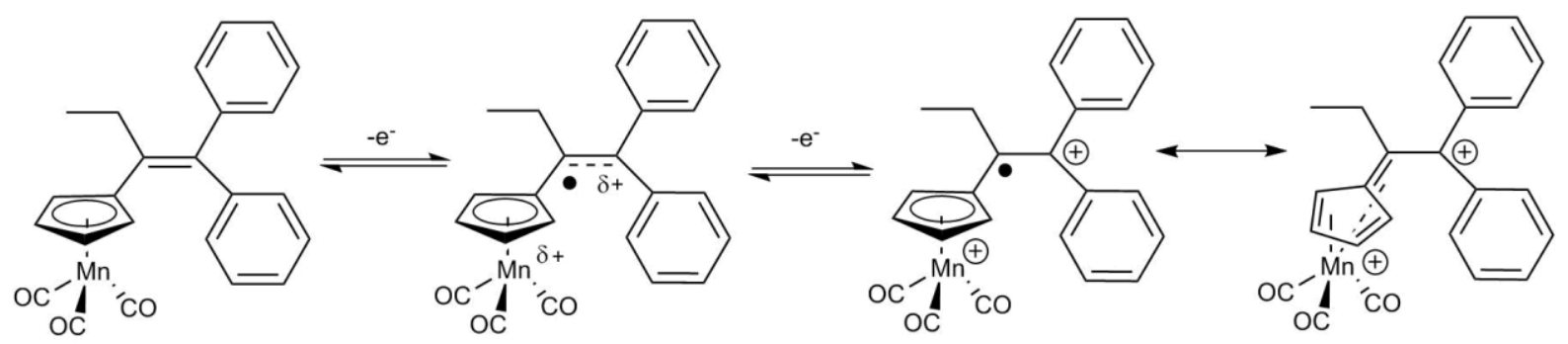

Figure 6. Representative structures of $\mathbf{1}, \mathbf{1}^{+}$, and $\mathbf{1}^{2+}$

More detailed information about the frontier orbitals of the three members of the electrontransfer series are obtained from examination of Figure 7. To understand the origin of the electron 
removed during oxidation, we divided $\mathbf{1}$ in four different fragments: Mn, cyclopentadienyl ring $(\mathrm{Cp})$, carbonyls, and the 1-ethyl-2-diphenyl-ethene (olefin) moiety. By inspecting the atomic orbital contribution of these fragments to the redox-active orbital, we can obtain the \%-contribution of each fragment. The HOMO of $\mathbf{1}$, found at an energy of $-5.668 \mathrm{eV}$, has about 2:1 ratio of $\pi$-ligand and organometallic character $\left(33 \% \mathrm{Mn}\left(\mathrm{C}_{5} \mathrm{H}_{4}\right)(\mathrm{CO})_{3}\right)$. Specifically, the HOMO of $\mathbf{1}$ consists of $13 \% \mathrm{Mn}$, $13 \% \mathrm{Cp}, 6 \% \mathrm{CO}$ and $67 \%$ olefin. The SOMO of $\mathbf{1}^{+}$shows a nearly identical distribution of $15,12,5$ and $68 \%$, respectively. This composition of the redox-active orbitals stands in stark contrast to the SOMO of the $\left[\mathrm{MnCp}(\mathrm{CO})_{3}\right]^{+}$-complex, which is formed by mixing $73 \% \mathrm{Mn}, 9 \% \mathrm{Cp}$ and $18 \% \mathrm{CO}$ based fragment orbitals. The redox-active orbital in $\mathbf{1}$ is derived from the interaction of the alkenyl $\pi$ MO with the non-bonding d(xy)-orbital of the low-spin Mn(I)- $d^{6}$ center that is aligned parallel to the cyclopentadienyl-plane. Removal of an electron from the HOMO of $\mathbf{1}$ leads to a substantial lowering of all orbital energies, with the singly occupied $\mathbf{1}^{+}$-SOMO being found at an electronic energy of $9.031 \mathrm{eV}$. Because the contribution of the organometallic fragment in 1-HOMO and $\mathbf{1}^{+}$-SOMO are essentially the same, as illustrated in Figure 7, the orbital shapes remain nearly identical, despite the somewhat severe changes in geometrical structure described above. Removal of the unpaired electron associated with $\mathbf{1}^{+}$-SOMO completes the oxidation and the resulting $94 \%$-ligand based LUMO of $\mathbf{1}^{2+}$ is found at an energy of $-10.898 \mathrm{eV}$.

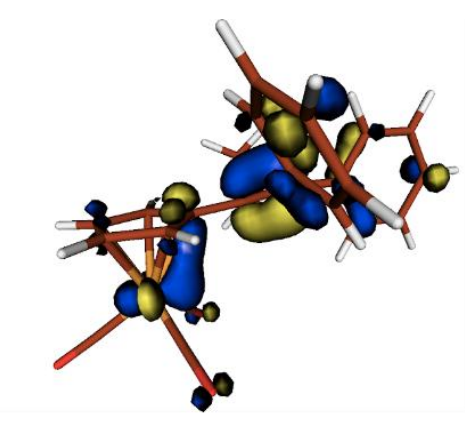

1-HOMO (-5.668 eV)
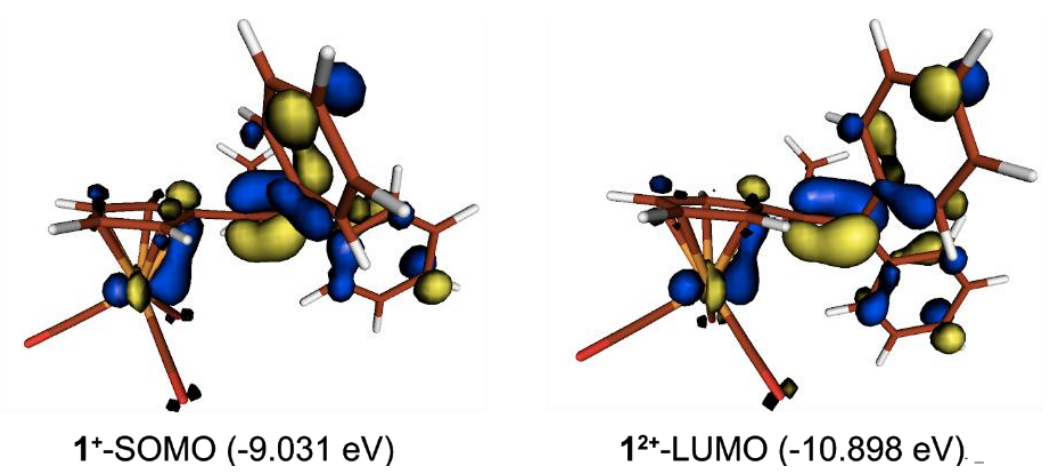

Figure 7. The redox-active orbitals of $\mathbf{1}, \mathbf{1}^{+}$and $\mathbf{1}^{2+}$. Isodensity value for the surface plots was set to 0.05 au.

The spectroscopic and computational data are in agreement that the stepwise oxidation of $\mathbf{1}$ involves orbitals that are delocalized between the cymantrenyl and diphenylethylenyl parts of the molecule, and that the redox orbital becomes more $\pi$-ligand based as the oxidation proceeds from the neutral complex to the corresponding dication. 
Redox-Switched Metal-Carbonyl Substitution. The fact that the radical cation $\mathbf{1}^{+}$contains significant cymantrenyl radical character suggests that the manganese carbonyl center should be susceptible to associative-driven CO substitution reactions. ${ }^{11,25,49-53}$ It is possible to take advantage of redox-dependent substitution rates in order to prepare $\mathrm{CO}$-substituted complexes having metals in either the 17-electron or 18-electron electronic configurations under mild conditions. The "electrochemical switch" method outlined in Eqs 2-4 shows how this might be carried out for a hypothetical metal complex $\mathrm{ML}_{\mathrm{n}}(\mathrm{CO})$. In this sequence, the neutral metal carbonyl

$$
\begin{aligned}
& \mathrm{ML}_{\mathrm{n}}(\mathrm{CO})-\mathrm{e}^{-} \rightleftharpoons\left[\mathrm{ML}_{\mathrm{n}}(\mathrm{CO})\right]^{+} \\
& {\left[\mathrm{ML}_{\mathrm{n}}(\mathrm{CO})\right]^{+}+\mathrm{L}^{\prime} \longrightarrow\left[\mathrm{ML}_{\mathrm{n}} \mathrm{L}^{\prime}\right]^{+}} \\
& {\left[\mathrm{ML}_{\mathrm{n}} \mathrm{L}^{\prime}\right]^{+}+\mathrm{e}^{-} \rightleftharpoons \mathrm{ML}_{\mathrm{n}} \mathrm{L}^{\prime},}
\end{aligned}
$$

complex is anodically oxidized to its radical cation (Eq2), which reacts with L', producing the radical cation of the substitution product (Eq 3). Owing to the fact that L' is invariably a stronger donor than $\mathrm{CO}$, the potential $\mathrm{E}_{1 / 2\left(\mathrm{ML}^{\prime}\right)}$ is less positive than $\mathrm{E}_{1 / 2(\mathrm{MCO})}$, assuring that the substitution product $\left[\mathrm{ML}_{\mathrm{n}} \mathrm{L}^{\prime}\right]^{+}$ remains in the positively-charged state as the electrolysis proceeds. $\left[\mathrm{ML}_{n} \mathrm{~L}^{\prime}\right]^{+}$may then be cathodically reduced to give the desired neutral substitution product (Eq 4), which is then extracted from the electrolyte solution. A literature example of this process is the preparation of $\mathrm{Cr}\left(\eta^{6}-\mathrm{C}_{6} \mathrm{H}_{6}\right)(\mathrm{CO})_{2} \mathrm{PPh}_{3}$ from $\mathrm{Cr}\left(\eta^{6}-\mathrm{C}_{6} \mathrm{H}_{6}\right)(\mathrm{CO})_{3} \cdot{ }^{54}$

Application of the electrochemical switch method to the preparation of the triphenylphosphite complex $\mathrm{Mn}(\mathrm{CO})_{2} \mathrm{P}(\mathrm{OPh})_{3}\left(\eta^{5}-\mathrm{C}_{5} \mathrm{H}_{4}(\mathrm{Et}) \mathrm{C}=\mathrm{C}\left(\mathrm{C}_{6} \mathrm{H}_{5}\right)_{2}\right)$ followed the expected protocol. Figure 8 shows a $\mathrm{CV}$ scan of 1 when a slight excess of $\mathrm{P}(\mathrm{OPh})_{3}$ is added to the solution. A reduction in the chemical reversibility of the $\mathbf{1}^{0 /+}$ couple is noted by comparing the scans taken before (dashed line) and after (solid line) addition of triphenylphosphite. The follow-up product is seen to have a reversible reduction at $\mathrm{E}_{1 / 2}=0.46 \mathrm{~V}$, consistent with the replacement of a single $\mathrm{CO}$ by $\mathrm{P}(\mathrm{OPh})_{3}$ in $\mathbf{1}$. The $\mathrm{E}_{1 / 2}$ shift of $0.32 \mathrm{~V}$ from that of $\mathbf{1}^{1 /+}$ is somewhat less than the average of $0.40 \mathrm{~V}$ observed for the $\mathrm{P}(\mathrm{OPh})_{3^{-}}$ for-CO shifts in cymantrene series $\mathrm{Mn}\left(\eta^{5}-\mathrm{C}_{5} \mathrm{H}_{4} \mathrm{R}\right)(\mathrm{R}=\mathrm{H}, \mathrm{Me}, \mathrm{I}, \mathrm{CHO}),{ }^{25}$ most likely reflecting the increased charge delocalization in $\mathbf{1}^{+}$. A triphenylphosphite substitution rate of $4.7 \times 10^{2} \mathrm{M}^{-1} \mathrm{~s}^{-1}$ was determined for $\mathbf{1}^{+}$by digital simulation, about an order of magnitude slower than that reported for the cymantrene radical cation. $^{25}$ 


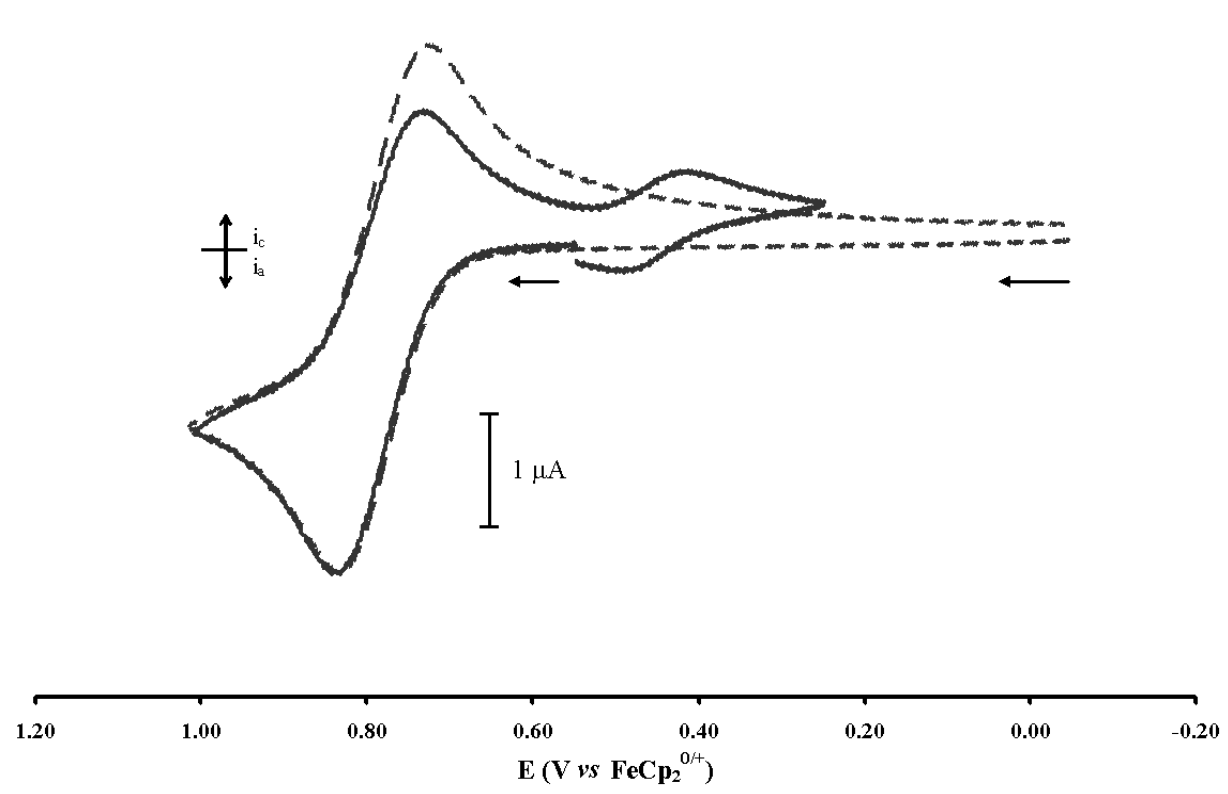

Figure 8. CVs of $1.0 \mathrm{mM} 1$ in the absence (dashed line) and the presence (solid line) of $1.5 \mathrm{mM}$ $\mathrm{P}(\mathrm{OPh})_{3}$ in $\mathrm{CH}_{2} \mathrm{Cl}_{2} / 0.05 \mathrm{M}\left[\mathrm{NBu}_{4}\right]\left[\mathrm{B}\left(\mathrm{C}_{6} \mathrm{~F}_{5}\right)_{4}\right]$ at $298 \mathrm{~K}, 0.2 \mathrm{~V} \mathrm{~s}^{-1}, 1 \mathrm{~mm} \mathrm{GCE}$.

Bulk anodic electrolysis $\left(\mathrm{E}_{\text {appl }}=0.9 \mathrm{~V}\right)$ of 1 in the presence of $\mathrm{P}(\mathrm{OPh})_{3}$ released $1 \mathrm{~F}$ of charge and gave a single product showing a reversible wave at $\mathrm{E}_{1 / 2}=0.46 \mathrm{~V}$ for the reduction of the COsubstituted cation $\left[\mathrm{Mn}(\mathrm{CO})_{2} \mathrm{P}(\mathrm{OPh})_{3}\left(\eta^{5}-\mathrm{C}_{5} \mathrm{H}_{4}(\mathrm{Et}) \mathrm{C}=\mathrm{C}\left(\mathrm{C}_{6} \mathrm{H}_{5}\right)_{2}\right)\right]^{+}$. Changing $\mathrm{E}_{\text {appl }}$ to $0.2 \mathrm{~V}$ required $1 \mathrm{~F}$ of charge and resulted in efficient conversion to neutral $\mathrm{Mn}(\mathrm{CO})_{2} \mathrm{P}(\mathrm{OPh})_{3}\left(\eta^{5}-\mathrm{C}_{5} \mathrm{H}_{4}(\mathrm{Et}) \mathrm{C}=\mathrm{C}\left(\mathrm{C}_{6} \mathrm{H}_{5}\right)_{2}\right)$. This sequence can be followed in Figure 9. The dotted line was recorded before beginning the anodic electrolysis and is analogous to the solid line in Figure 8. After completion of the electrolysis, the only electroactive compound in solution is the radical cation of the substitution product, responsible for the reversible cathodic wave at $0.46 \mathrm{~V}$ (dashed line). The solid line was recorded after completion of the cathodic "back-electrolysis" and arises from the reversible oxidation of the neutral substitution product, $\mathrm{Mn}(\mathrm{CO})_{2} \mathrm{P}(\mathrm{OPh})_{3}\left(\eta^{5}-\mathrm{C}_{5} \mathrm{H}_{4}(\mathrm{Et}) \mathrm{C}=\mathrm{C}\left(\mathrm{C}_{6} \mathrm{H}_{5}\right)_{2}\right)$. Comparison of the currents before and after the double electrolysis suggested that the in situ yield of $\mathrm{Mn}(\mathrm{CO})_{2} \mathrm{P}(\mathrm{OPh})_{3}\left(\eta^{5}-\mathrm{C}_{5} \mathrm{H}_{4}(\mathrm{Et}) \mathrm{C}=\mathrm{C}\left(\mathrm{C}_{6} \mathrm{H}_{5}\right)_{2}\right)$ was greater than $80 \% .{ }^{55}$ As described in the Experimental section, workup of the electrochemicallyswitched solution allowed isolation of the product, identified by its IR spectrum (Supporting Info Figure S1) in 40\% (un-optimized) yield. 


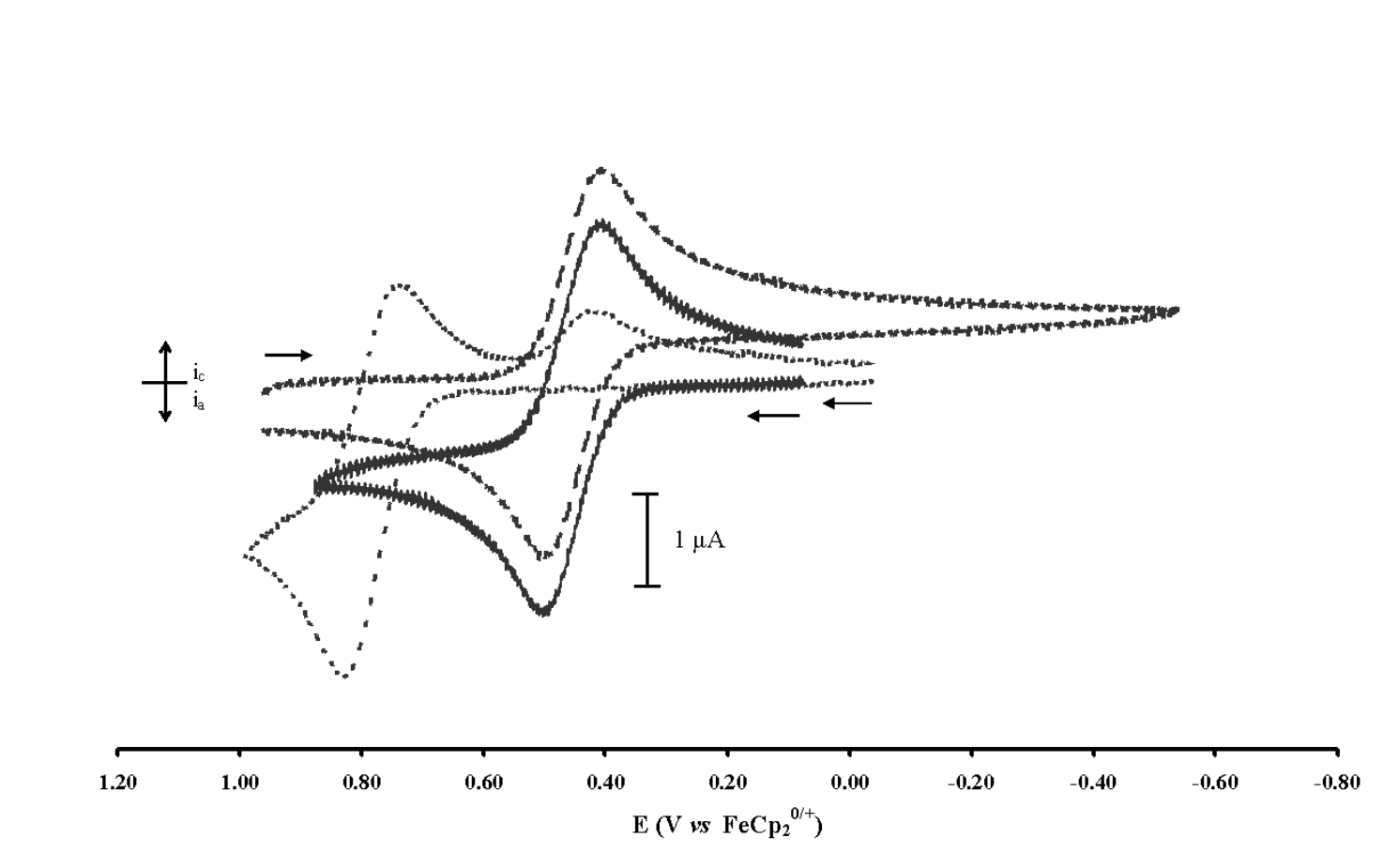

Figure 9. $\mathrm{CVs}$ of $1.0 \mathrm{mM} 1$ in the presence of $1.5 \mathrm{mM} \mathrm{P}(\mathrm{OPh})_{3}$ in $\mathrm{CH}_{2} \mathrm{Cl}_{2} / 0.05 \mathrm{M}\left[\mathrm{NBu}_{4}\right]\left[\mathrm{B}\left(\mathrm{C}_{6} \mathrm{~F}_{5}\right)_{4}\right]$ before (dotted line) and after (dashed line) bulk oxidation at $\mathrm{E}_{\text {appl }}=0.9 \mathrm{~V}$, and after bulk reduction (solid line) at $\mathrm{E}_{\mathrm{appl}}=0.2 \mathrm{~V}$ at $253 \mathrm{~K}, 0.2 \mathrm{~V} \mathrm{~s}^{-1}, 1 \mathrm{~mm} \mathrm{GCE}$.

In the case of three phosphites having smaller cone angles than $\mathrm{P}(\mathrm{OPh})_{3}$, examples of multiple CO substitution were observed. An example is shown in Figure 10, which gives the CVs of $\mathbf{1}$ in the presence of two different concentrations of $\mathrm{P}\left(\mathrm{O}^{i} \mathrm{Pr}\right)_{3}$. At a sub-stoichiometric concentration of the phosphite (long dashed line), product waves are seen at $\mathrm{E}_{1 / 2}$ values of $0.25 \mathrm{~V}$ and $-0.49 \mathrm{~V}$, which we attribute to the mono-substituted and di-substituted products, $\left[\mathrm{Mn}(\mathrm{CO})_{3-\mathrm{n}}\left[\mathrm{P}\left(\mathrm{O}^{\mathrm{i}} \mathrm{Pr}\right)_{3}\right]_{\mathrm{n}}\left(\eta^{5}-\right.\right.$ $\left.\left.\mathrm{C}_{5} \mathrm{H}_{4}(\mathrm{Et}) \mathrm{C}=\mathrm{C}\left(\mathrm{C}_{6} \mathrm{H}_{5}\right)_{2}\right)\right]^{+}, \mathrm{n}=2$ and 1 , respectively. With excess $\mathrm{P}\left(\mathrm{O}^{\mathrm{i}} \mathrm{Pr}\right)_{3}$ (solid line), only the more negative wave for the disubstituted product is observed. 


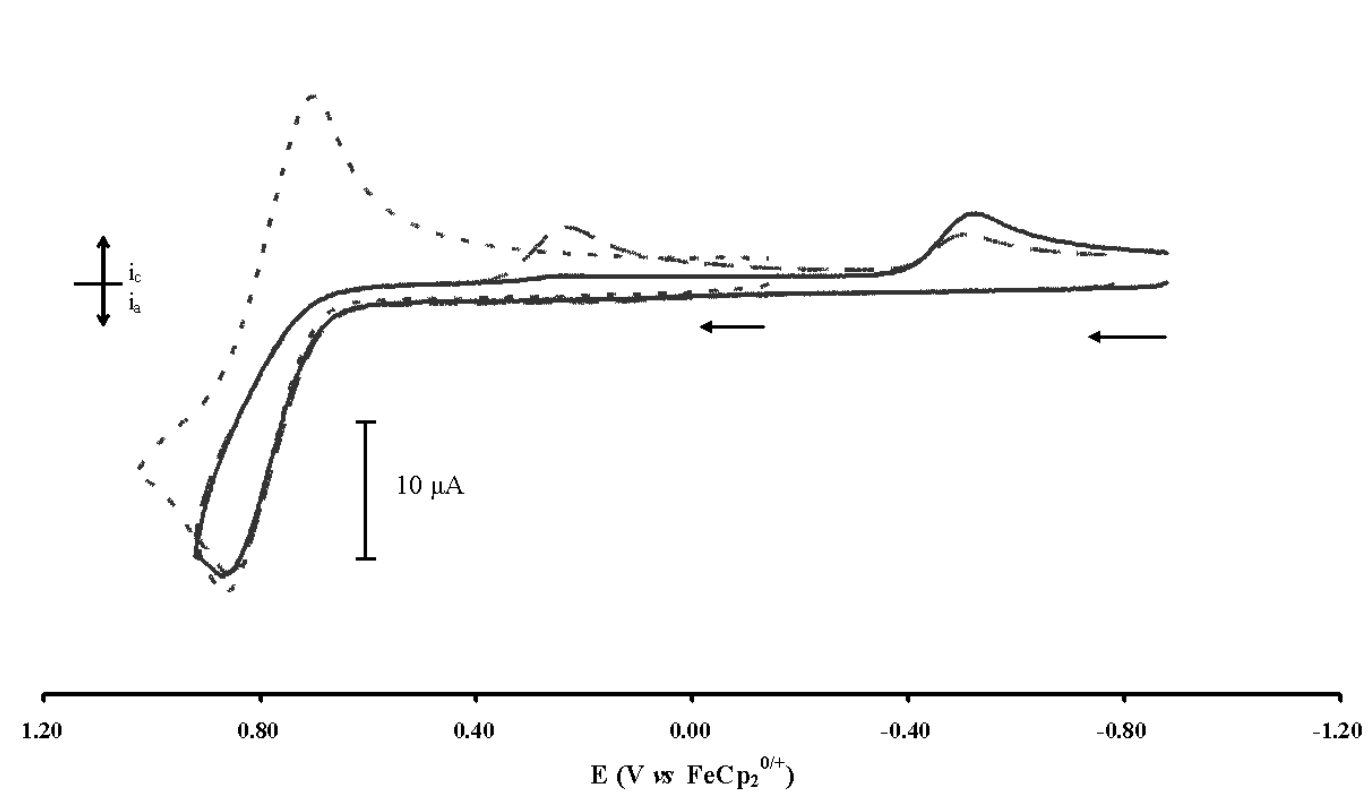

Fig 10. CVs of $0.90 \mathrm{mM} 1$ in the absence (dotted line), and the presence of $0.54 \mathrm{mM}$ (long dashed line) and $2.70 \mathrm{mM}$ (solid line) $\mathrm{P}(\mathrm{O}-i \mathrm{Pr})_{3}$ in $\mathrm{CH}_{2} \mathrm{Cl}_{2} / 0.05 \mathrm{M}\left[\mathrm{NBu}_{4}\right]\left[\mathrm{B}\left(\mathrm{C}_{6} \mathrm{~F}_{5}\right)_{4}\right]$ at $253 \mathrm{~K}, 0.2 \mathrm{~V}$ $\mathrm{s}^{-1}, 3 \mathrm{~mm}$ gc electrode.

Assignments of the new waves to $\mathrm{n}=1$ or $\mathrm{n}=2$ substitution products were made based on the expected shifts of the $E_{1 / 2}$ values from that $(0.78 \mathrm{~V})$ of the first oxidation of the tricarbonyl parent compound 1. Predictions of the shifts are possible for two phosphites for which the so-called "ligand electronic parameter" has been reported. ${ }^{57}$ This parameter was originally given as $\mathrm{E}_{\mathrm{L}}$ based on the oxidation of $\mathrm{Cr}(\mathrm{CO})_{5} \mathrm{~L}$ complexes $^{57}$. In concert with the slightly different shifts in $\mathrm{E}_{1 / 2}$ values that have been observed for $\mathrm{Mn}\left(\pi-\mathrm{C}_{5} \mathrm{H}_{4} \mathrm{R}\right)(\mathrm{CO})_{2} \mathrm{~L}$ complexes ${ }^{11,25,58}$ we use the symbol $\mathrm{E}_{\mathrm{L}}(\mathrm{cym})$ for the ligand electronic parameter of the cymantrene-family of complexes, including $\mathbf{1}$. As shown in Table 2, the $\mathrm{E}_{\mathrm{L}}(\mathrm{cym})$ values determined for $\mathrm{P}(\mathrm{OPh})_{3}$ and $\mathrm{P}(\mathrm{OMe})_{3}$ match well with those reported in previous literature, confirming the assignments of the mono-CO-substituted products. The similarity of the $\mathrm{E}_{\mathrm{L}}(\mathrm{cym})$ values for $\mathrm{P}\left(\mathrm{O}-{ }^{\mathrm{i}} \mathrm{Pr}\right)_{3}$ and $\mathrm{P}\left({ }^{\mathrm{n}} \mathrm{Bu}\right)(\mathrm{OEt})_{2}$ to that of $\mathrm{P}(\mathrm{OMe})_{3}$ suggest that these three ligands have essentially the same donor strengths.

The $\mathrm{CV}$ curves assigned to the second $\mathrm{CO}$-substitution products for $\mathrm{L}=\mathrm{P}(\mathrm{OMe})_{3}, \mathrm{P}\left(\mathrm{O}-{ }^{\mathrm{i}} \mathrm{Pr}\right)_{3}$, and $\mathrm{P}\left({ }^{\mathrm{n}} \mathrm{Bu}\right)(\mathrm{OEt})_{2}$ are again shifted to more negative potentials than observed for the singly-substituted products. The sequential shifts are essentially identical for the $\mathrm{L}=\mathrm{P}(\mathrm{OMe})_{3}$ system, for which the oxidation goes smoothly from $0.78 \mathrm{~V}$ to $0.24 \mathrm{~V}$ to $-0.31 \mathrm{~V}$ as $\mathrm{n}$ increases from 0 to 2 in $\mathrm{Mn}(\mathrm{CO})_{3-}$ ${ }_{\mathrm{n}}\left(\mathrm{P}(\mathrm{OMe})_{3}\right)_{\mathrm{n}}\left(\eta^{5}-\mathrm{C}_{5} \mathrm{H}_{4}(\mathrm{Et}) \mathrm{C}=\mathrm{C}\left(\mathrm{C}_{6} \mathrm{H}_{5}\right)_{2}\right)$. Somewhat larger shifts $(\mathrm{ca}-0.77 \mathrm{~V})$ for the apparent $\mathrm{n}=2$ products are seen for the other small phosphites, compared to values of only $-0.45 \mathrm{~V}$ for the first substitution products. We cannot rule out the possibility that the more highly-substituted products for 
$\mathrm{L}=\mathrm{P}(\mathrm{OMe})_{3}$ or $\mathrm{P}\left(\mathrm{O}-{ }^{\mathrm{i}} \mathrm{Pr}\right)_{3}$ are tri-substituted, but we think it more likely that the somewhat irregular shifts arise from electronic effects.

Table 2. Potentials vs ferrocene in $\mathrm{CH}_{2} \mathrm{Cl}_{2} / 0.05 \mathrm{M}\left[\mathrm{NBu}_{4}\right]\left[\mathrm{B}\left(\mathrm{C}_{6} \mathrm{~F}_{5}\right)_{4}\right]$ for the first oxidation of $\mathrm{Mn}(\mathrm{CO})_{3-\mathrm{n}} \mathrm{L}_{\mathrm{n}}\left(\eta^{5}-\mathrm{C}_{5} \mathrm{H}_{4}(\mathrm{Et}) \mathrm{C}=\mathrm{C}\left(\mathrm{C}_{6} \mathrm{H}_{5}\right)_{2}\right) .{ }^{\mathrm{a}}$ Reference 57. ${ }^{\mathrm{b}}$ Reference 25.

\begin{tabular}{|c|c|c|c|c|c|c|}
\hline Ligand $(\mathrm{L})$ & $\mathrm{n}$ & $\begin{array}{l}\mathrm{E}_{1 / 2} \\
(\mathrm{~V})\end{array}$ & $\begin{array}{l}\text { Shift from } \\
\mathrm{E}_{1 / 2} \text { of } \mathbf{1}(\mathrm{V})\end{array}$ & $\mathrm{E}_{\mathrm{L}}(\mathrm{cym})$ & $\mathrm{E}_{\mathrm{L}}(\mathrm{lit})$ & Comment \\
\hline $\mathrm{CO}$ & 0 & 0.78 & $\mathrm{n} . \mathrm{a}$ & 0.99 & $0.99^{\mathrm{a}}$ & \\
\hline $\mathrm{P}(\mathrm{OPh})_{3}$ & 1 & 0.46 & -0.32 & 0.67 & $0.62^{\mathrm{b}}$ & Literature $\mathrm{n} . \mathrm{a}$. \\
\hline $\mathrm{P}\left(\mathrm{O}{ }^{\mathrm{i}} \mathrm{Pr}\right)_{3}$ & 1 & 0.25 & -0.53 & 0.46 & ---- & Literature $\mathrm{n} . \mathrm{a}$. \\
\hline $\mathrm{P}(\mathrm{OMe})_{3}$ & 1 & 0.24 & -0.54 & 0.45 & $0.42^{\mathrm{a}}$ & \\
\hline $\mathrm{P}\left({ }^{\mathrm{n}} \mathrm{Bu}\right)(\mathrm{OEt})_{2}$ & 1 & 0.24 & -0.54 & 0.45 & ---- & \\
\hline $\mathrm{Pyridine}$ & 1 & -0.21 & -0.99 & 0 & $0.25^{\mathrm{a}}$ & \\
\hline $\mathrm{P}(\mathrm{OMe})_{3}$ & 2 & -0.31 & -1.09 & ---- & ---- & Additional shift of $-0.55 \mathrm{~V}$ from $\mathrm{n}=1$ \\
\hline $\mathrm{P}\left({ }^{\mathrm{n}} \mathrm{Bu}\right)(\mathrm{OEt})_{2}$ & 2 & -0.52 & -1.30 & ---- & ---- & Additional shift of $-0.76 \mathrm{~V}$ from $\mathrm{n}=1$ \\
\hline $\mathrm{P}\left(\mathrm{O}{ }^{\mathrm{i}} \mathrm{Pr}\right)_{3}$ & 2 & -0.53 & -1.31 & ---- & ---- & Additional shift of $-0.78 \mathrm{~V}$ from $\mathrm{n}=1$ \\
\hline
\end{tabular}

Redox-switched pyridine-for-CO substitution on the CV time scale was also observed for $\mathbf{1}$, as indicated in Figure 11, although the reaction was not complete in that case. The $\mathrm{E}_{1 / 2}$ of the pyridine substitution product $(-0.21 \mathrm{~V})$ is shifted positive by $0.99 \mathrm{~V}$ compared to the $0 /+$ potential of the tricarbonyl complex. IR spectra of a solution taken after a "redox switched" electrolysis had bands at $\sim 1930 \mathrm{~cm}^{-1}$ and $1845 \mathrm{~cm}^{-1}$ attributable to the $\mathrm{Mn}(\mathrm{CO})_{2}$ (pyridine) group [1933 and $1865 \mathrm{~cm}^{-1}$ reported for $\left.\mathrm{MnCp}(\mathrm{CO})_{2}(\mathrm{py})\right]^{59}$, but also showed bands for considerable unsubstituted material (SI, Figure S2). The $\mathrm{E}_{\mathrm{L}}(\mathrm{cym})$ value of 0 determined for $\mathrm{L}=$ pyridine (vide infra) is somewhat larger than that reported as its $\mathrm{E}_{\mathrm{L}}(0.25)^{57}$

The above data show that, by substitution of one or more carbonyls group by donor ligands, the oxidation potential of $\mathrm{Mn}(\mathrm{CO})_{3-\mathrm{n}} \mathrm{L}_{\mathrm{n}}\left(\eta^{5}-\mathrm{C}_{5} \mathrm{H}_{4}(\mathrm{Et}) \mathrm{C}=\mathrm{C}\left(\mathrm{C}_{6} \mathrm{H}_{5}\right)_{2}\right)$ can be altered by a volt or more, allowing the possibility of generating a family of compounds that is either easier or more difficult to oxidize than their ferrocenyl analogues. 


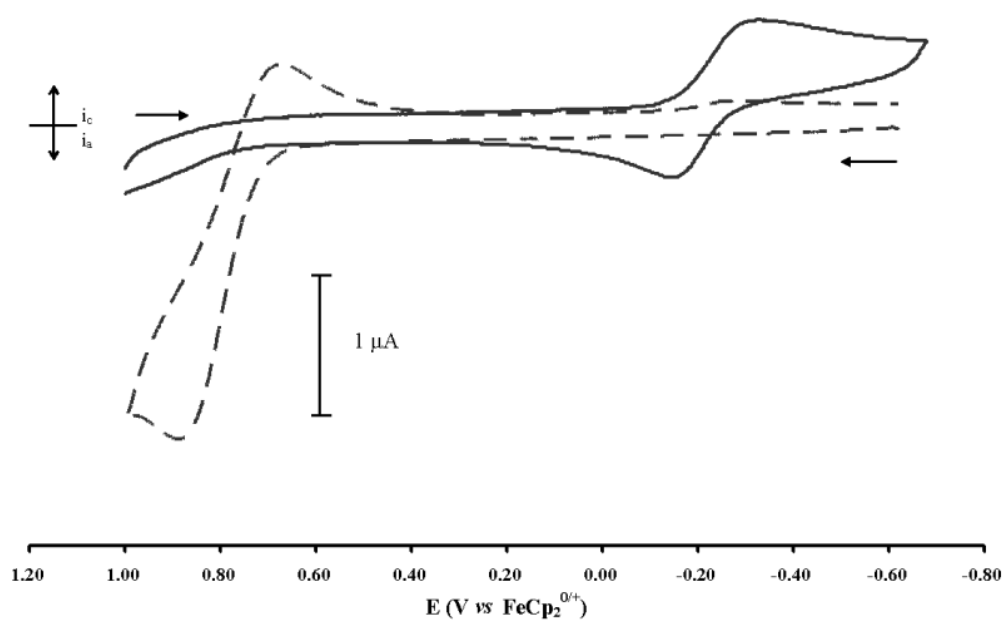

Figure 11. CVs $\left(0.2 \mathrm{~V} \mathrm{~s}^{-1}, 1 \mathrm{~mm}\right.$ gc electrode $)$ of $0.9 \mathrm{mM} 1$ in the presence of $2.7 \mathrm{mM}$ pyridine before (dashed line) and after (solid line) bulk oxidation $\left(\mathrm{E}_{\text {appl }}=0.9 \mathrm{~V}\right)$ in $\mathrm{CH}_{2} \mathrm{Cl}_{2} / 0.05 \mathrm{M}\left[\mathrm{NBu}_{4}\right]\left[\mathrm{B}\left(\mathrm{C}_{6} \mathrm{~F}_{5}\right)_{4}\right]$ at $253 \mathrm{~K}$.

Conclusions. Based on the known differences in oxidative redox potentials between cymantrene, ferrocene, and the diphenylethylene moiety, the observation that the first oxidation of 1 occurs at a much higher potential $(0.78 \mathrm{~V})$ than that of the ferrocenyl analogue $4(\approx 0 \mathrm{~V})^{21,56}$ was expected. Interestingly, however, this process involves loss of an electron from a HOMO orbital of $\mathbf{1}$ that is highly delocalized over the entire organometallic/ $\pi$-organic framework, leading to a welldistributed sharing of positive charge in the monocation $\mathbf{1}^{+}$. There is sufficient positive charge at the $\mathrm{Mn}(\mathrm{CO})_{3}$ group of $\mathbf{1}^{+}$to facilitate the rapid substitution of one or more $\mathrm{CO}$ ligands by donor ligands, including several phosphites and pyridine. The resulting CO-substituted compounds have much milder oxidation potentials, in some cases being easier to oxidize than 4 . The fact that the SOMO of the radical cation $\mathbf{1}^{+}$has mixed organometallic/ $\pi$-organic character, and the finding that the fraction of positive charge on the organic segment increases as electrons are removed, will be helpful in understanding both the follow-up reactions and the thermodynamic potential shifts that accompany the oxidations of analogues having more reactive groups in the phenyl rings. ${ }^{14}$ Electrochemical and computational studies of the $p$-hydroxy and $p$-methoxy derivatives of $\mathbf{1}$ will be detailed in a separate paper.

\section{Notes}

The authors declare no competing financial interest. 


\section{Acknowledgment}

M.H.B. acknowledges support from the Institute for Basic Science (IBS-R10-D1) in Korea. 


\section{References}

1. (a) Jordan, V.C., Antiestrogens and Selective Estrogen Receptor Modulators as Multifunctional Medicines. 1. Receptor Interactions. J. Med. Chem. 2003, 46, 883-908 (b) Jordan, V.C., Antiestrogens and Selective Estrogen Receptor Modulators as Multifunctional Medicines. 2. Clinical Considerations and New Agents. J. Med. Chem. 2003, 46, 1081-1111 (c) Jordan, V.C., Linking Estrogen-Induced Apoptosis with Decreases in Mortality Following Long-term Adjuvant Tamoxifen Therapy. J. Natl. Cancer Inst. 2014, 106 (11), dju296.

2. Wu, X.; Hawse, J.R.; Subramaniam, M.; Goetz, M.P.; Ingle, J.N.; Spelsberg, T.C. The Tamoxifen Metabolite, Endoxifen, is a Potent Antiestrogen that Targets Estrogen Receptor A for Degradation in Breast Cancer Cells. Cancer Res. 2009, 69, 1722-1727.

3. Early Breast Cancer Trialists' Collaborative Group (EBCTCG), Relevance of Breast Cancer Hormone Receptors and other Factors to the Efficacy of Adjuvant Tomoxifen: Patient-level Metaanalysis of Randomised Trials. Lancet 2011, 378, 771-184.

4. Vessières, A.; Top, S.; Beck, W.; Hillard, E.A.; Jaouen, G., Metal Complex SERMS (Selective Estogen Receptor Modulators). The Influence of Different Metal Units on Breast Cancer Cell Antiproliferative Effects. Dalton Trans., 2006, 529-541.

5. Jaouen, G.; Vessières, A.; Top, S., Ferrocifen Type Anti-cancer Drugs. Chem. Soc. Rev., 2015, 44, 8802-8817, and references therein.

6. Lee, H.Z.S.; Buriez, O.; Chau, F.; Labbé, E.; Ganguly, R.; Amatore, C.; Jaouen, G.; Vessières, A.; Leong, W.K.; Top, S. Synthesis, Characterization, and Biological Properties of Osmium-Based Tamoxifen Derivatives-Comparison with their Homologues in the Iron and Ruthenium Series. Eur. J. Inorg. Chem. 2015, 4217-4226.

7. Hillard, E.A.; Vessières, A.; Top, S.; Pigeon, P.; Kowalski, K.; Huché, Jaouen, G., Organometallic Diphenols: The Importance of the Organometallic Moiety on the Expression of a Cytotoxic Effect on Breast Cancer Cells. J. Organometal. Chem. 2007, 692, 1315-1326.

8. Dallagi, T.; Saidi, M.; Jaouen, G.; Top, S. Synthesis and Antiproliferative Activity of (Z + E)-1-[4(2-(cyclopentadienyltricarbonylmanganese)-2-oxo-ethoxy)phenyl]-1,2-di(p-hydroxyphenyl)-but-1-ene Against Breast Cancer Cells. Appl. Organomet. Chem. 2013, 27, 28-35.

9. Dallagi, T.; Saidi, M.; Vessières, A.; Huché, M.; Jaouen, G.; Top, S. Synthesis and Antiproliferative Evaluation of Ferrocenyl and Cymantrenyl Triaryl Butene on Breast Cancer Cells. J. Organometal. Chem. 2013, 734, 69-77.

10. Connelly, N.G.; Geiger, W.E. The Electron-Transfer Reactions of Mononuclear Organotransition Metal Complexes. Adv. Organomet. Chem. 1984, 23, 49-52.

11. Kochi, J.K. Electron Transfer and Transient Radicals in Organometallic Chemistry. $J$. Organometal. Chem. 1986, 300, 139-166.

12. Atwood, C.G.; Bitterwolf, T.E.; Geiger, W.E. Anodic Infrared Spectroelectrochemistry of Monoand Di-Nuclear Complexes Containing the $\left(\mathrm{C}_{5} \mathrm{H}_{4} \mathrm{R}\right) \mathrm{Mn}(\mathrm{CO})_{2} \mathrm{~L}$ Moiety $\left(\mathrm{L}=\mathrm{CO}\right.$ or $\left.\mathrm{PR}_{3}\right)$. Journal Electroanal. Chem. 1995, 397, 279-285.

13. Pike, R.D.; Rieger, A.L.; Rieger, P.H. Dramatic Tensor-Axis Non-Coincidence in the ESR Spectra of Some Low-Spin Mn(II) Complexes. J. Chem. Soc., Faraday Trans. 1 1989, 85, 3913-3925.

14. Wu, K.; Top, S.; Hillard, E.A.; Jaouen, G.; Geiger, W.E. Anodic Properties of Diarylethene Derivatives Having Organometallic Piano-Stool Tags. Chem. Commun. 2011, 10109-10111. 
15. Phelps, J.; Bard, A.J. One- vs Two-Electron Oxidations of Tetraarylethylenes in Aprotic Solvents. J. Electroanal. Chem. 1976, 68, 313-335.

16. Aalstad, B.; Parker, V.D. Normalized Potential Sweep Voltammetry. Part IV. Analysis of Overlapped Voltammetric Waves for Closely-Spaced Consecutive Charge Transfers. J. Electroanal. Chem. 1982, 136, 251-258.

17. Rathoe, R.; Lindeman, S.V.; Kumar, A.S.; Kochi, J.K. Disproportionation and Structural Changes of Tetraarylethylene Donors upon Successive Oxidation to Cation Radicals and to Dications. J. Am. Chem. Soc. 1998, 120, 6931-6939.

18. Schreivogel, A.; Maurer, J.; Winter, R.; Baro, A.; Laschat, S. Synthesis and Electrochemical Properties of Tetrasubstituted Tetraphenylethenes. Eur. J. Org. Chem. 2006, 3395-3404. The potentials in this paper are reported vs ferrocene/ferrocenium. Values reported vs other reference electrodes (see refs 16-18) would give similar potentials when converted to the ferrocene reference.

19. Talipov, M.R.; Boddeda, A.; Hossain, M.M.; Rathore, R. Quantitative Generation of Cation Radicals and Dications Using Aromatic Oxidants: Effect of Added Electrolyte on the Redox Properties of Aromatic Electron Donors. J. Phys. Org. Chem. 2016, 29, 227-233.

20. Mori, T.; Inoue, Y. Chiral Organic Radical Cation and Dication. A Reversible Chiroptical Redox Switch Based on Stepwise Transformation of Optically Active Tetrakis( $p$-alkoxyphenyl)ethylenes to Radical Cations and Dications. J. Phys. Chem. A 2005, 109, 2728-2740.

21. (a) Hillard, E.; Vessières, A.; Thouin, L.; Jaouen, G.; Amatore, C. Ferrocene-Mediated ProtonCoupled Electron Transfer in a Series of Ferrocifen-Type Breast-Cancer Drug Candidates. Angew. Chem. Int. Ed. 2006, 45, 285-290 (b) Messina, P.; Labbé, E.; Buriez, O.; Hillard, E.A.; Vessiéres, A.; Hamels, D.; Top, S.; Jaouen,G.; Frapart, Y.M; Mansuy, D.; Amatore, C. Deciphering the Activation Sequence of Ferrociphenol Anticancer Drug. Chem. Eur. J. 2012, 18, 6581-6587.

22. Tan, Y.L.K.; Pigeon, P.; Hillard, E.A.; Top, S.; Plamont, M-A.; Vessières, A.; McGlinchey, M.J.; Müller-Bunz, H.; Jaouen, G. Synthesis, Oxidation Chemistry and Cytotoxicity Studies on Ferrocene Derivatives of Diethylstilbestrol. Dalton Trans. 2009, 10871-10881.

23. Hillard, E.; Vessières, A.; Le Bideau, F.; Plaz, D.; Spera, D.; Huché, M.; Jaouen, G. A Series of Unconjugated Ferrocenyl Phenols: Prospects as Anticancer Agents. ChemMedChem, 2006, 551-559.

24. Laws, D.R.; Chong, D.; Nash, K.; Rheingold, A.L.; Geiger, W.E. Cymantrene Radical Cation Family: Spectral and Structural Characterization of the Half-Sandwich Analogues of Ferrocenium Ion. J. Amer. Chem. Soc. 2008, 130, 9859-9870.

25. Wu, K.; Laws, D.R.; Nafady, A.; Geiger, W.E. Substitution of CO ligand by $\mathrm{P}(\mathrm{OPh})_{3}$ in Radical Cations of the Cymantrene Family: Relationship of Substitution Rates to $\mathrm{E}_{1 / 2}$ Values and Carbonyl IR Frequencies J. Inorg. Organometal. Polym. 2014, 24, 137-144.

26. Shaw, M.J.; Geiger, W. A New_Approach to Infrared Spectroelectrochemistry Using a Fiber-Optic Probe: Application to Organometallic Redox Chemistry. Organometallics 1996, 15, 13-15.

27. LeSuer, R.J.; Buttolph, C., Geiger, W.E. Comparison of the Conductivity Properties of the Tetrabutylammonium Salt of Tetrakis(pentafluorophenyl)borate Anion with Those of Traditional Supporting Electrolyte Anions in Nonaqueous Solvents. Anal. Chem. 2004, 76, 6395-6401.

28. Fischer, E.O.; Fellman, W. Aromatic Complexes of Metals. LXII. Acylation of Cyclopentadienyl Rhenium Tricarbonyl and Cyclopentadienyl Technicium Tricarbonyl. J. Organomet. Chem. 1963, 1, 191-199. 
29. (a) Gritzner, G.; Kuta, J. Recommendations on Reporting Electrode Potentials in Nonaqueous Solvents. Pure Appl. Chem. 1984, 56, 461-466 (b) Connelly, N.G.; Geiger, W.E. Chemical Redox Agents for Organometallic Chemistry. Chem. Rev. 1996, 96, 877-910.

30. Gagne, R.E.; Koval, C.A.; Lisensky, G.C. Ferrocene as an Internal Standard for Electrochemical Measurements. Inorg. Chem. 1980, 19, 2854-2855.

31. (a) Bard, A.J.; Faulkner, L.R. Electrochemical Methods, John Wiley \& Sons, New York, $2^{\text {nd }}$ Ed., 2001, Chapter 6 (b) Geiger, W.E. in Kissinger, P.T.; Heineman, W.R. (Eds) Laboratory Techniques in Electroanalytical Chemistry, Marcel Dekker, Inc., $2^{\text {nd }}$ Ed., 1996, Chapter 23.

32. Grimme, S.; Antony, J. ; Ehrlich, S. ; Krieg, H. A Consistent and Accurate ab initio Parametrization of Density Functional Dispersion Correction(DFT-D) for the 94 Elements H-Pu. $J$. Chem. Phys. 2010, 132, 154104

33. Shao, Y. ; Gan, Z.; Epifanovsky, E.; Gilbert, A. T. B.; Wormit, M.; Kussmann, J.; Lange, A. W.; Behn, A.; Deng, J.; Feng, X.; Ghosh, D.; Goldey, M.; Horn, P. R.; Jacobson, L. D.; Kaliman, I.; Khaliullin, R. Z.; Kuś, T.; Landau, A.; Liu, J.; Proynov, E. I.; Rhee, Y. M.; Richard, R. M.; Rohrdanz, M. A.; Steele, R. P.; Sundstrom, E. J.; Woodcock, H. L.; Zimmerman, P. M.; Zuev, D.; Albrecht, B.; Alguire, E.; Austin, B.; Beran, G. J. O.; Bernard, Y. A.; Berquist, E.; Brandhorst, K.: Bravaya, K. B.; Brown, S. T.; Casanova, D.; Chang, C.-M.; Chen, Y.; Chien, S. H.; Closser, K. D.; Crittenden, D. L.; Diedenhofen, M.; DiStasio, R. A.; Do, H.; Dutoi, A. D.; Edgar, R. G.; Fatehi, S.; Fusti-Molnar, L.; Ghysels, A.; Golubeva-Zadorozhnaya, A.; Gomes, J.; Hanson-Heine, M. W. D.; Harbach, P. H. P.; Hauser, A. W.; Hohenstein, E. G.; Holden, Z. C.; Jagau, T.-C.; Ji, H.; Kaduk, B.; Khistyaev, K.; Kim, J.; Kim, J.; King, R. A.; Klunzinger, P.; Kosenkov, D.; Kowalczyk, T.; Krauter, C. M.; Lao, K. U.; Laurent, A. D.; Lawler, K. V.; Levchenko, S. V.; Lin, C. Y.; Liu, F.; Livshits, E.; Lochan, R. C.; Luenser, A.; Manohar, P.; Manzer, S. F.; Mao, S.-P.; Mardirossian, N.; Marenich, A. V.; Maurer, S. A.; Mayhall, N. J.; Neuscamman, E.; Oana, C. M.; Olivares-Amaya, R.; O’Neill, D. P.; Parkhill, J. A.; Perrine, T. M.; Peverati, R.; Prociuk, A.; Rehn, D. R.; Rosta, E.; Russ, N. J.; Sharada, S. M.; Sharma, S.; Small, D. W.; Sodt, A.; Stein, T.; Stück, D.; Su, Y.-C.; Thom, A. J. W.; Tsuchimochi, T.; Vanovschi, V.; Vogt, L.; Vydrov, O.; Wang, T.; Watson, M. A.; Wenzel, J.; White, A.; Williams, C. F.; Yang, J.; Yeganeh, S.; Yost, S. R.; You, Z.-Q.; Zhang, I. Y.; Zhang, X.; Zhao, Y.; Brooks, B. R.; Chan, G. K. L.; Chipman, D. M.; Cramer, C. J.; Goddard, W. A.; Gordon, M. S.; Hehre, W. J.; Klamt, A.; Schaefer, H. F.; Schmidt, M. W.; Sherrill, C. D.; Truhlar, D. G.; Warshel, A.; Xu, X.; AspuruGuzik, A.; Baer, R.; Bell, A. T.; Besley, N. A.; Chai, J.-D.; Dreuw, A.; Dunietz, B. D.; Furlani, T. R.; Gwaltney, S. R.; Hsu, C.-P.; Jung, Y.; Kong, J.; Lambrecht, D. S.; Liang, W.; Ochsenfeld, C.; Rassolov, V. A.; Slipchenko, L. V.; Subotnik, J. E.; Van Voorhis, T.; Herbert, J. M.; Krylov, A. I.; Gill, P. M. W.; Head-Gordon, M. Advanced in Molecular Quantum Chemistry Contained in the QChem 4 Program Package. Molecular Physics 2015, 113, 184-215.

34. Hehre, W. J.; Ditchfield, R.; Pople, J. A. Self-Consistent Molecular Orbital Methods. XII. Further Extensions of Gaussian-Type BAsis SEts for Use in Molecular Orbital Studies of Organic Molecules. J. Chem. Phys. 1972, 56, 2257.

35. Hay, P. J.; Wadt, W. R. ab initio Effective Core Potentials for Molecular Calculations. Potentials for the Transition Metal Atoms Sc to Hg. J. Chem. Phys. 1985, 82, 270-283.

36. Dunning Jr., T. H. Gaussian Basis Sets for Use in Correlated Molecular Calculations. I. The Atoms Boron through Neon and Hydrogen. J. Chem. Phys. 1989, 90, 1007-1023.

37. Baik, M.-H.; Friesner, R. A. Computing Redox Potentials in Solution: Density Functional Theory as A Tool for Rational Design of Redox Agents. J. Phys. Chem. A 2002, 106, 7407-7412.

38. Wohlfarth, C. Static Dielectric Constants of Pure Liquids and Binary Liquid Mixtures. In Supplement to IV/6, ed. M. D. Lechner, Springer Berlin Heidelberg, Berlin, Heidelberg, 2008, pp. 6768. 
39. $C C C B D B$ listing of precalculated vibrational scaling factors. https://cccbdb.nist.gov/vibscalejust.asp (Accessed 2 Mar. 2018).

40. chemissian v4.52, www.chemissian.com (accessed Nov 02, 2017)

41. Goldman, A.S.; Krogh-Jespersen, K. Why Do Cationic Carbon Monoxide Complexes Have High C-O Stretching Force Constants and Short C-O Bonds? Electrostatic Effects, Not $\sigma$-Bonding. J. Am. Chem. Soc. 1996, 118, 12159-12166.

42. Ehlers, A.W.; Ruiz-Morales, Y.; Baerends, E.J.; Ziegler, T. Dissociation Energies, Vibrational Frequencies, and ${ }^{13} \mathrm{C}$ NMR Chemical Shifts of the 18-Electron Species $\left[\mathrm{M}(\mathrm{CO})_{6}\right]^{\mathrm{n}}(\mathrm{M}=\mathrm{Hf}-\mathrm{Ir}, \mathrm{Mo}, \mathrm{Tc}$, $\mathrm{Ru}, \mathrm{Cr}, \mathrm{Mn}, \mathrm{Fe})$. A Density Functional Study. Inorg. Chem. 1997, 36, 5031-5036.

43. Willner, H.; Aubke, F. Homoleptic Metal Carbonyl Cations of the Electron-Rich Metals: Their Generation in Superacid Media Together with Their Spectroscopic and Structural Characterization. Angew. Chem. Int. Ed. 1997, 36, 2402-2425.

44. Niu, S.; Thomson, L.M.; Hall, M.B. Theoretical Characterization of the Reaction Intermediates in a Model of the Nickel-Iron Hydrogenase of Desulfovibrio gigas. J. Am. Chem. Soc. 1999, 121, 40004007.

45. Xu, Q. Metal Carbonyl Cations: Generation, Characterization and Catalytic Application. Coord. Chem. Rev. 2002, 231, 83-108.

46. Borden, W. T. Pyramidalized Alkene. Chem. Rev. 1989, 89, 5, 1095-1109.

47. (a) Gleiter, R.; Bleiholder, C.; Rominger, F. $\alpha$-Mettallocenylmethylium Ions and Isoelectronic Fulvene Complexes of $\mathrm{d}^{6}$ to $\mathrm{d}^{9}$ Metals. Structural Considerations. Organometallics 2007, 26, 48504859 (b) Bleiholder, C.; Rominger, F.; Gleiter, R. $\alpha$-Mettallocenylmethylium Ions and Their Iosoelectronic Congeners: A Comparison Based on DFT Calculations. Organometallics 2009, 28, 1014-1017.

48. Volland, M.A.O.; Kudis, S.; Helmchen, G.; Hyla-Kryspin, I.; Rominger, F.; Gleiter, R. Structure and Bonding Properties of the Complex $\left(\eta^{5}\right.$-Diphenylfulvene $) \mathrm{Mn}(\mathrm{CO})_{3}{ }^{+}$. Organometallics 2001, 20 , 227-230.

49. Chong, , D.; Laws, D.R.; Nafady, A.; Costa, P.J.; Rheingold, A.L.; Calhorda, M.J. Geiger, W.E. $\left[\mathrm{ReCp}(\mathrm{CO})_{3}\right]^{+}$Family of 17-Electron Compounds: Monomer/Dimer Equilibria and Other Reactions. $J$. Am. Chem. Soc. 2008, 130, 2692-2073.

50. Orpen, A.G.; Connelly, N.G. Structural Systematics: The Role of P-A $\sigma^{*}$ Orbitals in Metalphosphorus n-Bonding in Redox Pairs of M-PA ${ }_{3}$ Complexes. Organometallics 1990, 9, 1206-1210.

51. Therien, M.J.; Ni, C-L.; Anson, F.C.; Osteryoung, J.G.; Trogler, W.C. Kinetics of Disproportionation of Tricarbonylbis(phosphine) iron(I) Cation Radicals by Differential Pulse Chronocoulometry. J. Am. Chem. Soc. 1986, 107, 4037-4042.

52. Basolo, F. Ring-slippage Mechanism and Kinetics of CO Substitution of Metal Carbonyls. New. J. Chem. 1994, 18, 19-24.

53. Geiger, W.E. Organometallic Electrochemistry: Origins, Development, and Future. Organometallics 2007, 26, 5738-5765.

54. Ohrenberg, N.C.; Paradee, L.M.; Dewitte III, R.J.; Chong, D.; Geiger, W.E. Spectra and SyntheticTime-Scale Substitution Reactions of Electrochemically Produced $\left[\mathrm{Cr}(\mathrm{CO})_{3}\left(\eta^{6} \text {-arene }\right)\right]^{+}$Complexes. Organometallics 2010, 29, 3179-3186. 
55. Currents in the cyclic and linear scan voltammograms are proportional to the square root of the diffusion coefficient of the analyte. The diffusion coefficient of the triphenylphosphite derivative is expected to be considerably lower than that of the tricarbonyl complex, owing to its higher molecular weight. For a discussion of how variations in molecular weight affect the diffusion coefficients in a family of molecules, see Flanagan, J.B.; Margel, S.; Bard, A.J.; Anson, F.A. Electron Transfer To and From Molecules Containing Multiple Noninteracting Redox Centers. Electrochemical Oxidation of Poly(vinylferrocene). J. Am. Chem. Soc. 1978, 100, 4248-4253.

56. In reference 21 , the $\mathrm{E}_{1 / 2}$ potential of 4 is given as $0.02 \mathrm{~V}$ vs S.C.E. in methanol/[ $\left.\mathrm{NBu}_{4}\right]\left[\mathrm{BF}_{4}\right]$. Conversion to the ferrocene potential is an estimate.

57. Lever, A.B.P. Electrochemical Parameterization of Metal Complex Redox Potentials Using the Ruthenium(II)/Ruthenium(III) Couple to Generate an Electrochemical Series. Inorg. Chem 1990, 29, 1271-1285.

58. Atwood, C.G.; Geiger, W.E.; Bitterwolf, T.E. Anodic Infrared Spectroelectrochemistry of Monoand Dinuclear Complexes Containing the $\left(\eta^{5}-\mathrm{C}_{5} \mathrm{H}_{4}\right) \mathrm{Mn}(\mathrm{CO})_{2} \mathrm{~L}$ moiety $\left(\mathrm{L}=\mathrm{CO}\right.$ or $\left.\mathrm{PR}_{3}\right) . J$. Electroanal. Chem. 1995, 397, 279-285.

59. Giordano, P.J.; Wrighton, M.S. Photosubstitution Behavior of Dicarbonyl $\left(\eta^{5}-\right.$ cyclopentadienyl)pyridinomanganese and -rhenium and Related Complexes. Inorg. Chem 1977, 16, 160-166.

\section{Table of Contents}

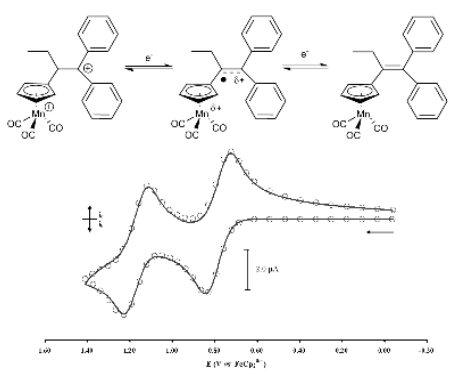


Supporting information

\section{Oxidation of Cymantrene Analogues of Ferrocifen: Electrochemical, Spectroscopic, and Computational Studies of the Parent Complex, 1,1'- Diphenyl, 2-cymantrenylbutene}

Kan Wu,${ }^{\dagger}$ Ji Young Park, ${ }^{\ddagger}$ Rachael Al-Saadon,,$"$ Hyerim Nam, $,{ }^{\ddagger}, \perp$ Yujin Lee, ${ }^{\ddagger}{ }^{,}, \perp$ Siden Top, ${ }^{\#}$ Gérard Jaouen,, ,

Mu Hyun Baik ${ }^{\ddagger, \delta},{ }^{*}$ and William E. Geiger ${ }^{\dagger, *}$

'Department of Chemistry, University of Vermont, Burlington, VT 05405, USA,

${ }^{\ddagger}$ Center for Catalytic Hydrocarbon Functionalizations, Institute for Basic Science (IBS), Daejeon 34141, South Korea.

${ }^{\S}$ Department of Chemistry, Korea Advanced Institute of Science and Technology (KAIST), Daejeon 34141, South Korea.

"Department of Chemistry, Duke University, Durham, NC 27708, USA

${ }^{\#}$ Sorbonne Université, UPMC, CNRS, Institut Parisien de Chimie Moléculaire (IPCM), UMR 8232, 4 place Jussieu, 75005 Paris, France

${ }^{\nabla}$ PSL, Chimie Paris Tech, 11 rue Pierre and Marie Curie, F-75005 Paris, France $\perp$ Presentt address: Samsung Electronics, Suwon 16677, South Korea

*Corresponding author: William.Geiger@uvm.edu, mbaik2805@kaist.ac.kr 
Figure S1. IR spectrum of isolated $\mathrm{Mn}(\mathrm{CO})_{2} \mathrm{P}(\mathrm{OPh})_{3}\left(\eta^{5}-\mathrm{C}_{5} \mathrm{H}_{4}(\mathrm{Et}) \mathrm{C}=\mathrm{C}\left(\mathrm{C}_{6} \mathrm{H}_{5}\right)_{2}\right)$ in $\mathrm{CH}_{2} \mathrm{Cl}_{2}$.

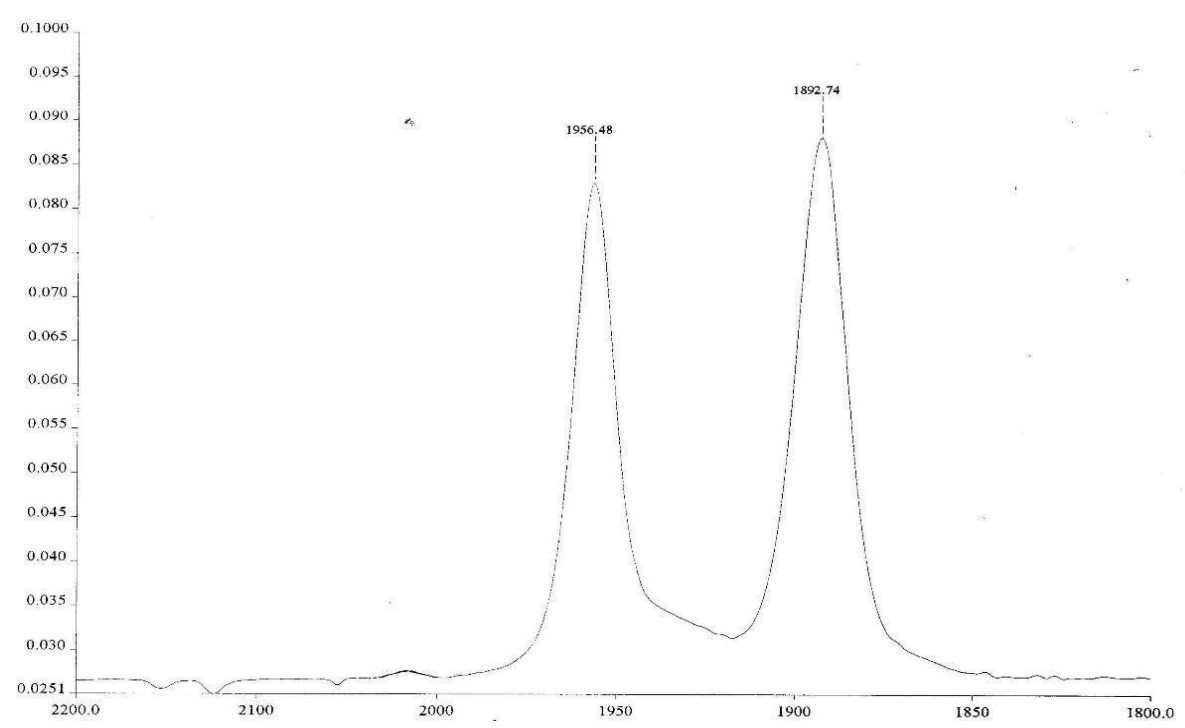

Figure S2. IR spectrum of $0.9 \mathrm{mM} 1$ in the presence of $2.7 \mathrm{mM}$ pyridine after "redox switch" electrolyses in $\mathrm{CH}_{2} \mathrm{Cl}_{2} / 0.05 \mathrm{M}\left[\mathrm{NBu}_{4}\right][\mathrm{TFAB}]$ at $253 \mathrm{~K}$.

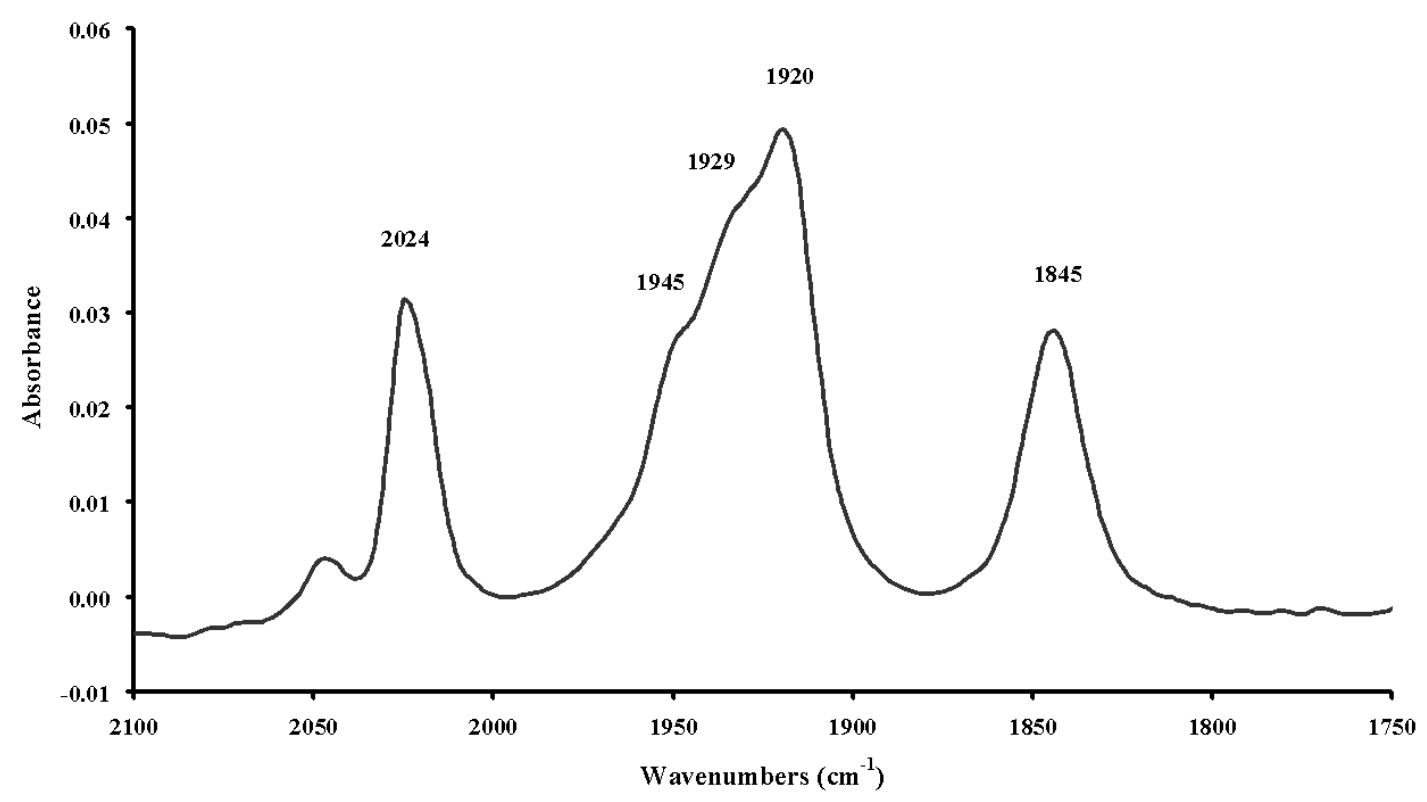




\section{xyz-coordinates from calculations}

1

$\begin{array}{llll}M n & -2.5922756939 & -0.2374841745 & 0.1733444883\end{array}$

C $\quad-1.7997399657 \quad-0.0723310400 \quad-1.8395682048$

C $\quad-3.3480429689-1.8058862455-0.2450775673$

C $\quad-0.7497331197 \quad 0.2460486665 \quad-0.9259832869$

$\begin{array}{llll}\text { C } & -2.8633653941 & 0.8644836483 & -1.6787974884\end{array}$

$\begin{array}{llll}\text { C } & -1.2007848969 & 1.3922768805 & -0.1716074535\end{array}$

$\begin{array}{llll}\text { C } & -2.4775219337 & 1.7718324707 & -0.6509415092\end{array}$

$\begin{array}{llll}\text { C } & -3.9682472589 & 0.2603433951 & 1.2090166030\end{array}$

C $\quad-1.6343811236 \quad-0.9107379269 \quad 1.5258099809$

H $\quad-1.7929443120 \quad-0.8969929810 \quad-2.5371613031$

$\begin{array}{llll}\text { H } & -3.7856417450 & 0.8843385689 & -2.2408044715\end{array}$

H $\quad-0.6468919562 \quad 1.8817157175 \quad 0.6133969475$

$\begin{array}{llll}\text { H } & -3.0740568660 & 2.5903142813 & -0.2724900375\end{array}$

$\begin{array}{llll}\text { O } & -4.8574798025 & 0.6203246546 & 1.8543360273\end{array}$

$\begin{array}{llll}\text { O } & -0.9381452895 & -1.3192569438 & 2.3554351961\end{array}$

$\begin{array}{llll}\text { O } & -3.8116626322 & -2.8152953465 & -0.5683444560\end{array}$

C $\quad 0.4954679633 \quad-0.5263504899 \quad-0.7330178845$

C $\quad 1.6396695222 \quad 0.0325304046 \quad-0.2608296714$

C $\quad 0.4203355884-1.99854755594-1.1141694628$

H $\quad 1.0078927869-2.6020432336-0.4207172971$

H $\quad-0.6134555630 \quad-2.3446149015 \quad-1.0244043766$

$\begin{array}{llll}\text { C } & 0.9418332426 & -2.2428722699 & -2.5418234509\end{array}$

H $\quad 1.9988034128 \quad-1.9677402774 \quad-2.6102139645$

H $\quad 0.3939358581 \quad-1.6477725867 \quad-3.2804230255$

H $\quad 0.8438463580 \quad-3.2979496172 \quad-2.8179048732$

C $\quad 1.8469166716 \quad 1.5010813069-0.1353640633$

$\begin{array}{llll}\text { C } & 2.2841849548 & 2.0590675203 & 1.0763216688\end{array}$

C $\quad 1.6244901849 \quad 2.3531225904 \quad-1.2292433890$

$\begin{array}{llll}\text { C } & 2.4499766097 & 3.4375847103 & 1.2028135912\end{array}$ 


$\begin{array}{llll}\text { C } & 1.8013028862 & 3.7300764615 & -1.1062291095 \\ \text { C } & 2.2060849104 & 4.2779819788 & 0.1132265257 \\ \text { H } & 2.4791372735 & 1.4032957023 & 1.9198531450 \\ \text { H } & 1.3035925855 & 1.9235541118 & -2.1737962901 \\ \text { H } & 2.7720255068 & 3.8564487699 & 2.1518729681 \\ \text { H } & 1.6240668869 & 4.3746269557 & -1.9625716311 \\ \text { C } & 2.7985275946 & -0.8091983326 & 0.1600162810 \\ \text { C } & 4.0269893971 & -0.7273402973 & -0.5108064219 \\ \text { C } & 2.6842357778 & -1.6650288908 & 1.2670599501 \\ \text { C } & 5.1096361395 & -1.5061803198 & -0.1031197707 \\ \text { C } & 3.7705503372 & -2.4365718999 & 1.6803949202 \\ \text { C } & 4.9841758315 & -2.3626414699 & 0.9933317697 \\ \text { H } & 4.1236331779 & -0.0516459685 & -1.3558678398 \\ \text { H } & 1.7362008334 & -1.7175110956 & 1.7958642902 \\ \text { H } & 6.0522625554 & -1.4431260020 & -0.6394211817 \\ \text { H } & 3.6684118740 & -3.0934412524 & 2.5395153749 \\ \text { H } & 5.8292180511 & -2.9656517912 & 1.3126897496 \\ \text { H } & 2.3395452775 & 5.3513106917 & 0.2115826296\end{array}$
$1^{+}$
$\begin{array}{llll}M n & -2.0377588271 & -0.2849517269 & 0.4898302192\end{array}$
C $\quad-1.9982846959-0.2891834713-1.6808517334$
$\begin{array}{llll}\text { C } & -1.9864378379 & -2.0974034673 & 0.5601379397\end{array}$
C $\quad-0.7580317728 \quad 0.2603239946-1.1597640742$
$\begin{array}{llll}\text { C } & -3.0662785257 & 0.5332697626 & -1.2858005823\end{array}$
C $\quad-1.1428473098 \quad 1.4495416944 \quad-0.4086329945$
$\begin{array}{lllll}\text { C } & -2.5341875269 & 1.6137279497 & -0.5031945117\end{array}$
C $\quad-3.5611282377 \quad-0.2267586512 \quad 1.4822995619$
$\begin{array}{llll}\text { C } & -0.9724201899 & -0.0639709953 & 1.9430082362\end{array}$
H $\quad-2.0906610588 \quad-1.1858090030-2.2749023239$
H $\quad-4.1092211527 \quad 0.3723766966 \quad-1.5199549018$ 

H $\quad-0.4762126461 \quad 2.1044404935 \quad 0.1276366453$
H $\quad-3.1088997986 \quad 2.4068102195 \quad-0.0458284307$
$\begin{array}{llll}\text { O } & -4.5341533631 & -0.1680486485 & 2.0870311298\end{array}$
$\begin{array}{llll}\text { O } & -0.2362069281 & 0.1040037927 & 2.8096582495\end{array}$
$\begin{array}{llll}\text { O } & -1.9102069734 & -3.2447592283 & 0.5615176762\end{array}$
$\begin{array}{llll}\text { C } & 0.4792468069 & -0.4698027427 & -1.0968306583\end{array}$
$\begin{array}{llll}\text { C } & 1.6231831170 & 0.0330592428 & -0.4173190096\end{array}$
C $\quad 0.5490595860 \quad-1.7962016759-1.8282117656$
H $\quad 1.4108709478 \quad-2.3674795122 \quad-1.4863195379$
H $\quad-0.3351552015 \quad-2.4071736935 \quad-1.6245409032$
$\begin{array}{llll}\text { C } & 0.6878542539 & -1.5651377006 & -3.3504719086\end{array}$
H $\quad 1.6076818645 \quad-1.0189736644 \quad-3.5790081157$
H $\quad-0.1534026968 \quad-0.9973376422 \quad-3.7579277150$
$\begin{array}{llll}\text { H } & 0.7302873507 & -2.5283519110 & -3.8660493761\end{array}$
$\begin{array}{llll}\text { C } & 1.8977406367 & 1.4694731436 & -0.3534549988\end{array}$
$\begin{array}{llll}\text { C } & 2.3414258613 & 2.0622085431 & 0.8496822426\end{array}$
$\begin{array}{lllll}\text { C } & 1.7140275231 & 2.2847885130 & -1.4929557378\end{array}$
$\begin{array}{llll}\text { C } & 2.5581502288 & 3.4347846609 & 0.9155324561\end{array}$
C $\quad 1.9614718700 \quad 3.6495987049 \quad-1.4279216592$
$\begin{array}{llll}\text { C } & 2.3743243789 & 4.2290279624 & -0.2214587503\end{array}$
H $\quad 2.4669745340 \quad 1.4425896246 \quad 1.7312108801$
H $\quad 1.3947033752 \quad 1.8305630200 \quad-2.4258492640$
H $\quad 2.8701045490 \quad 3.8870546825 \quad 1.8512596051$
H $\quad 1.8370133944 \quad 4.2649313077 \quad-2.3131602168$
$\begin{array}{llll}\text { C } & 2.5338658541 & -0.8785879967 & 0.2693770062\end{array}$
$\begin{array}{llll}\text { C } & 3.9202188603 & -0.6044660499 & 0.3291914597\end{array}$
$\begin{array}{llll}\text { C } & 2.0425382220 & -2.0303875163 & 0.9316729834\end{array}$
C $\quad 4.7811686113 \quad-1.4633928545 \quad 1.0020651073$
C $\quad 2.9038614149 \quad-2.8714836302 \quad 1.6205790589$
$\begin{array}{llll}\text { C } & 4.2768043257 & -2.5943759139 & 1.6521481891\end{array}$
H $\quad 4.3114407193 \quad 0.2648953644 \quad-0.1876302492$ 


$$
\begin{array}{llll}
H & 0.9777086973 & -2.2385865970 & 0.9254427151 \\
H & 5.8459599137 & -1.2556144467 & 1.0191029988 \\
H & 2.5115516425 & -3.7399250211 & 2.1399425148 \\
H & 4.9496224920 & -3.2591968366 & 2.1846598003 \\
H & 2.5552132394 & 5.2980377977 & -0.1697646315
\end{array}
$$

$$
1^{2+}
$$$$
\begin{array}{llll}
M n & -1.9102761267 & -0.4658045038 & 0.5283323975
\end{array}
$$$$
\text { C } \quad-2.0881432323 \quad-0.1495262684-1.6185786694
$$$$
\begin{array}{llll}
\text { C } & -1.9035994303 & -2.2958033893 & 0.3634356549
\end{array}
$$$$
\text { C } \quad-0.8192225166 \quad 0.3511406503 \quad-1.0845120677
$$$$
\text { C } \quad-3.1246716286 \quad 0.5858641652 \quad-1.0473288144
$$$$
\text { C } \quad-1.1718053659 \quad 1.4371353559 \quad-0.1564628553
$$$$
\begin{array}{llll}
\text { C } & -2.5590076500 & 1.5675193691 & -0.1463209075
\end{array}
$$$$
\text { C } \quad-3.4493184688 \quad-0.5694615182 \quad 1.5412175435
$$$$
\begin{array}{llll}
\text { C } & -0.9041688304 & -0.3864737748 & 2.0588032286
\end{array}
$$$$
\text { H } \quad-2.2059435515 \quad-0.9499562404 \quad-2.3341979810
$$$$
\text { H } \quad-4.1809700659 \quad 0.4371641571 \quad-1.2306585694
$$$$
\text { H } \quad-0.4778902493 \quad 2.0298276198 \quad 0.4192410150
$$$$
\begin{array}{llll}
\text { H } & -3.1259185727 & 2.2701670454 & 0.4501780519
\end{array}
$$$$
\begin{array}{llll}
\text { O } & -4.4065301667 & -0.6234199563 & 2.1575859794
\end{array}
$$$$
\begin{array}{llll}
\text { O } & -0.2326677527 & -0.3053641732 & 2.9810199402
\end{array}
$$$$
\begin{array}{lllll}
\text { O } & -1.8606638642 & -3.4282714966 & 0.2151670386
\end{array}
$$$$
\begin{array}{llll}
\text { C } & 0.3551828078 & -0.4149643227 & -1.0442730241
\end{array}
$$$$
\begin{array}{llll}
\text { C } & 1.5624626739 & 0.0800512244 & -0.3278974182
\end{array}
$$$$
\text { C } \quad 0.5184682958-1.6248282549-1.9381491852
$$$$
\text { H } \quad 1.2581158809-2.3060883107 \quad-1.5160218783
$$$$
\text { H } \quad-0.4171294249 \quad-2.1790710489 \quad-2.0268432351
$$$$
\text { C } \quad 0.9907715450 \quad-1.1789233321 \quad-3.3455028083
$$$$
\text { H } \quad 1.9512202044 \quad-0.6579201971-3.3019245715
$$

$\begin{array}{llll}\text { H } & 0.2551305512 & -0.5234752514 & -3.8212530687\end{array}$ 

H $\quad 1.1179622855-2.0633459660-3.9743606855$
$\begin{array}{llll}\text { C } & 1.9174927556 & 1.4676931950 & -0.4579745298\end{array}$
C $\quad 2.5553768349 \quad 2.1570724675 \quad 0.6165200605$
$\begin{array}{llll}\text { C } & 1.6246647061 & 2.1871046890 & -1.6559536537\end{array}$
$\begin{array}{llll}\text { C } & 2.8774590409 & 3.4985682246 & 0.4925141503\end{array}$
C $\quad \begin{array}{llll}1.9911754020 & 3.5148153193 & -1.7816801114\end{array}$
$\begin{array}{llll}\text { C } & 2.6096789726 & 4.1757878798 & -0.7071959024\end{array}$
H $\quad 2.7197201951 \quad 1.6417294855 \quad 1.5563106072$
H $\quad 1.1667062604 \quad 1.6748717707 \quad-2.4952164596$
$\begin{array}{llll}\text { H } & 3.3267743062 & 4.0276647820 & 1.3262539891\end{array}$
H $\quad 1.8039605565 \quad 4.0446775575 \quad-2.7096990882$
$\begin{array}{llll}\text { C } & 2.3671734539 & -0.8384775211 & 0.4197705051\end{array}$
C $\quad 3.7658960575 \quad-0.5965318392 \quad 0.5938937148$
$\begin{array}{llll}\text { C } & 1.8185685779 & -2.0341799771 & 0.9768098340\end{array}$
$\begin{array}{llll}\text { C } & 4.5525854082 & -1.4838217202 & 1.3092889738\end{array}$
$\begin{array}{llll}\text { C } & 2.6067592176 & -2.9028826347 & 1.7032268538\end{array}$
$\begin{array}{llll}\text { C } & 3.9773220058 & -2.6297033547 & 1.8748875980\end{array}$
$\begin{array}{llll}\text { H } & 4.2262186791 & 0.2477354886 & 0.0947385032\end{array}$
$\begin{array}{llll}\text { H } & 0.7624154947 & -2.2432751591 & 0.8603019660\end{array}$
$\begin{array}{llll}\text { H } & 5.6174255647 & -1.3035649358 & 1.4105227319\end{array}$
H $\quad 2.1731003493 \quad-3.7939577326 \quad 2.1447847608$
$\begin{array}{llll}\text { H } & 4.5961908332 & -3.3237402821 & 2.4356143094\end{array}$
$\begin{array}{llll}\text { H } & 2.8745275084 & 5.2243892884 & -0.8032312978\end{array}$ 